\title{
STUDIES ON THE CONGENITAL LATERAL CERVICAL FISTULAS AND CYSTS
}

By

KENJI AIMI M.D.

\section{From the Department of Oto-Rhino-Laryngology, School of Medicine, Keio University (Director: Prof. Yasunobu, Suzuki M.D.)}

Lateral cervical fistulas and cysts are thought to be derived from bronchial cleft remnants, but there are still disputes as to the exact etiology of these anomalies.

In order to obtain better understanding concerning the pathogenesis and varieties of clinical manifestations, correlation between the embryology of the branchial clefts and clinical pictures are required.

Using nine human embryos, ranging between $8 \mathrm{~mm}$ to $50 \mathrm{~mm}$ in size, development and disappearance of branchial cleft structures were observed. Anatomical features of the fistulas derived from each cleft remnant were discussed.

Concerning the pathogenesis of this anomalies, numerous theories has been proposed. In spite of exhaustive research work of Wengelowski, his thymic duct theory has its weakness and is largely abandoned at present. Frazer's suggestion concerning its etiology is most convincing, in which he maintains that fistulas and cysts are derived from any one of numerous lateral vestigial struc. tures of the neck.

Reviewing cases appeared in the world literature, the author tried to classify the fistulas and cysts according to the first through the fourth cleft origin. Although the second cleft anomaly is the most common one, the first and the third cleft anomalies must be taken into consideration. Anomalies of the first and the third cleft are reported from the author's experience.

Related anomalies and differential diagnosis: were reviewed briefly.

\section{先天性側頸部瘻管及び囊腫に関する考察}

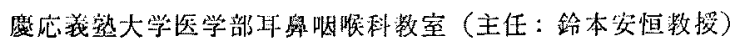

講 師相見賢治

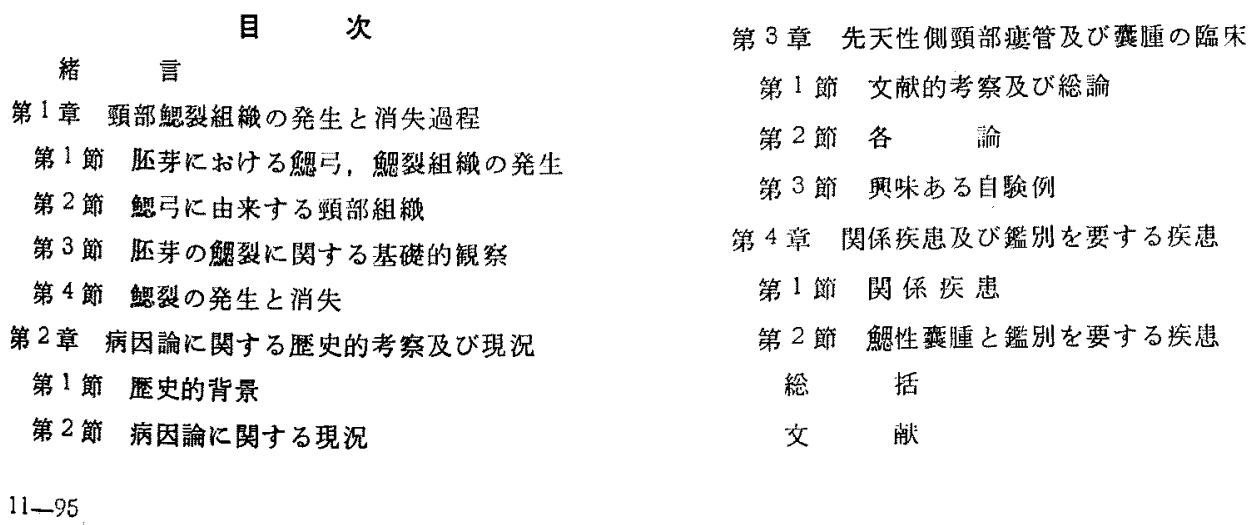


緒

言

頸部に見られる先天性疾患の中で側頸部度管及び琶腫 は，その大部分のものが肧莱期の一過性構造である鰓裂 組穖の遗残を主原因とするものと考えられる。

この疾患の成因に関しては過去に種々の学説が出され てきた，現在ではほぼ一致した病因説が出てはいるが臨 床例の中にはその成因の追求の困難なるが少なくな i.

その故にこの種の突患の成因を考察し，諸学説及び臨 林像の各型について一応の知識を持つことは頸部のこの 種の先天性渏型の理解にも臨床治㿟の面からも必要であ ると考觉られる。

著者はヒトの胎生初期の鰓裂，鰓亏構造を肧茅及び胎 胃の連続切片標本について観察し，発生学書の記載と対 比しつつ正常所見につき総括した。

次にこの疾患の病因に関する諸説を述へ，臨床例につ いて考察を試子た，最後に臨床上必要な鑑別すべき疾患 について言及した。

\section{第 1 章 頸部鰓裂組稞の発生と消失過程}

第1節 肧芽に扣ける鰓亏，鮊裂組織の発生

ヒトの発生初期，胚荐が $2.6 \mathrm{~mm}$ (頂股長，10日目 頃) から約 $14 \mathrm{~mm}$ (7 週目頃) の間に限定して还莱頸部 の内外胚葉面に鰓马鰓裂構造が出現する．即ちこの期間 に泼茅の頸部にあたる位置には外肧葉面に 4 条の鰓溝と それを狭んで5詨の鮊马が見られる。

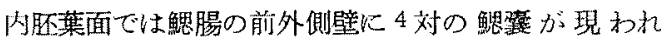
る。鱾琵は背側，腹側の角を有する粼曲した溝として垷 われる。

これ等の鰓性組織は貨椎動物の系統発生の上から見た 原始呼吸器管がヒトの発生初期に一過性に出現する構造 である。

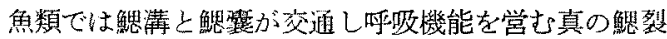
を作るが，ヒトでは鳃清（Branchial groove）と鲤霍 (Branchial pauch) は交通することなく，その中間に 中脴華組穖を狭えで相対し，最も接近する部分でも短期 間, 内外二肧葉性の閐鎖膜（Closing membrane）を形 成するのみである。

その意味ではヒトには舅裂 (Branchial cleft) は存 在しない加けであるが，本論文では便宜上鰓裂を鰓海及

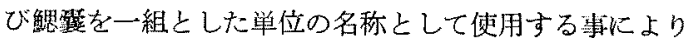
記述を簢略化することにする。

この用語法に従うと，七トでは第2遻上り第7週の間 に肧契の頚部には，左右 5 対の鰓马と，その鰓弓を狭儿

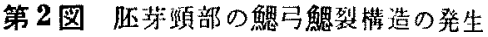

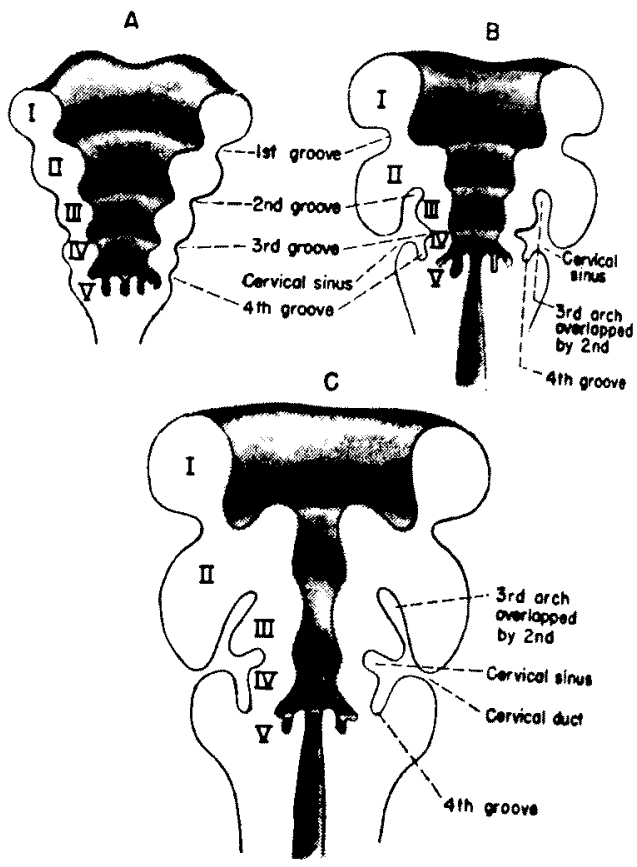

A 第 1 上り第 4 の鰓裂が見られる.

第 5 鰓露は痕跡的に見られる。

B 第 2 鰓弓が延びて頸洞を形成する.

C 莖頁洞は殆んど閉鎖され頙管を通して外界と 違絡する所を示す。

Ward and Headricks 1: "Tumors of the Head \& Neck" より怡㳦

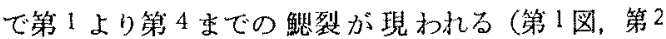
国).

各鰓弓の成長に伴つて鰓列は短期間で項点に達し急速 に消失する、鰓裂構造が失われると鳃马は相互に融合し 頸部が次第に形成されると共に鰓马由来の臟器は分化し 始める。

夫々の鰓弓が頸部のいら゙れの部分を構成しているか， 鰓裂の位置がどこに相当するかルついては一心の模型が 考党られる（第3図）が夷際は梅雑で簡単に图示する事 は困難である。

その理由の一つは頸部の発生様式の特性にある，発生 初期の直立している肧来は頸部の成長では背側が腹側よ り早いため，胚考の頭部は強く前屈して下顎が心隆起に 接触する位置を取る。胎児の生長と共に心隆起より頭部 は分離して，再び直立し，頸部が構成される。 


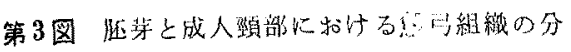
桶状態

Bill, A.H. Jr. and Vadheim, J.I.? の諭交より伀㖪

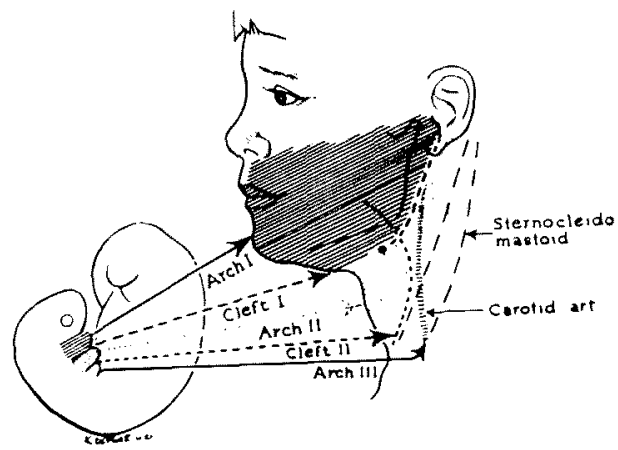

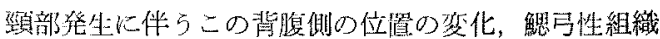

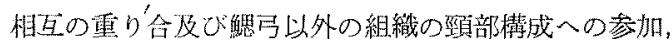

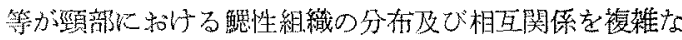
ものにしている。

第2 節 媳屉に由来する頸部組織

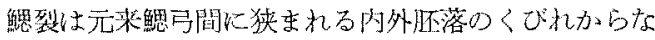

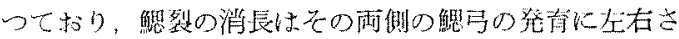

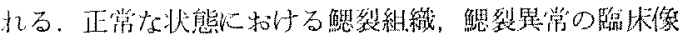

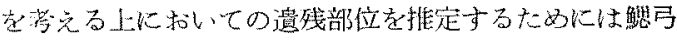
山来の組織を知古必要がある。第1表は第1上り第5ま での鳃马由来の組織を，上皮，骨骼，筋肉，神程，䢐管 についで表にしたものである。

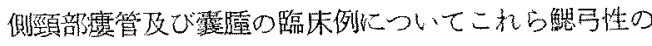

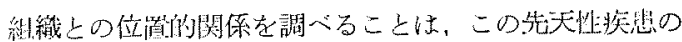

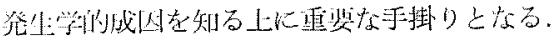

第 1 表

\begin{tabular}{|c|c|c|c|c|c|c|}
\hline 䊼織 & & 1 & $\|$ & III & N & $V$ \\
\hline 骨 & 髅 & 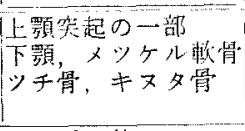 & 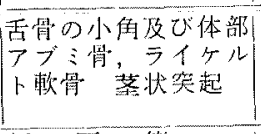 & 舌骨の大解 & 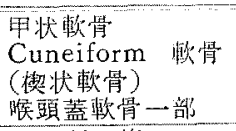 & 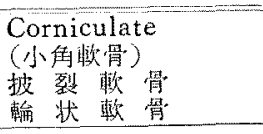 \\
\hline 筋 & 肉 & 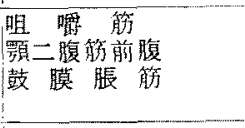 & 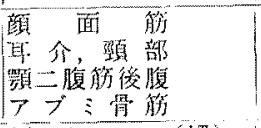 & 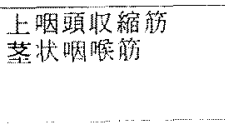 & 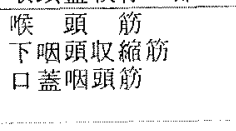 & 㸻 䫂 筋 \\
\hline 神 & 释 & 三又神释（V) & 浭的 & 舌眙神 経 (X) & 迷起神経 $(X)$ & 副＼cjkstart神＼cjkstart経（X) \\
\hline III & 管 & 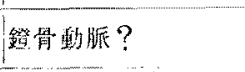 & 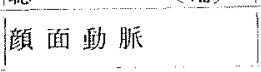 & 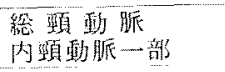 & $\begin{array}{l}\text { 压大動脈 } \\
\text { 在鎖骨下動朖 }\end{array}$ & $\begin{array}{l}\text { 胋 動 } \\
\text { Ductus Arteriosus }\end{array}$ \\
\hline 波 & 成 & 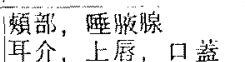 & 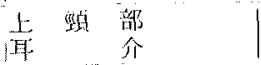 & 中 培 部 & 外企に詨はれれ & 下鼎部の一部 \\
\hline 粘 & 膜 & $\begin{array}{l}\text { 舌, For. caecum } \\
\text { まで } \\
\text { 口腔粘膜 }\end{array}$ & $\begin{array}{l}\text { 舌 枇部 } \\
\text { 舌甲状腺管 }\end{array}$ & 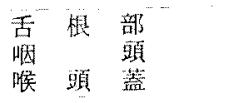 & 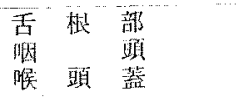 & \\
\hline
\end{tabular}

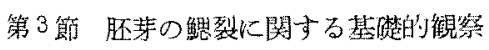
発生学のこの分野に括ける研焭は His 以来 Wengelowski 3), Frazer ${ }^{4)}$ 等, 多くの㧘者によつてなされ て来大，著者は既に定説となつてはいるが再確諗与るた

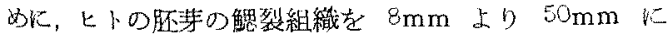
至る肧芽及び胎胃 9 体につき連続切片橴本により調企し

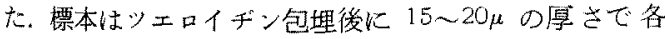
種の方向火切片を作りへマトキシン・エオヂン重染色を 行的った。

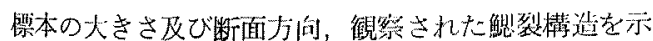

せば，第 2 裴の如くでるる。の表で明らかな如く鰓裂 の見られるのは肧等 6 7 图以前に限られ，16 $\mathrm{mm}$ 以上 の肧牙には触裂構造は見られない。

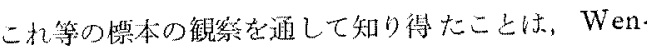

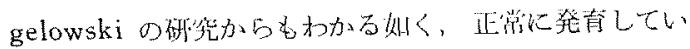

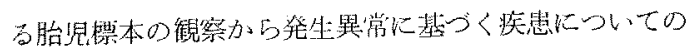
推䛺を下すことには注意を要す事ですつた。

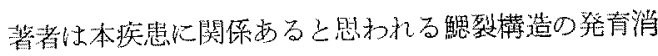

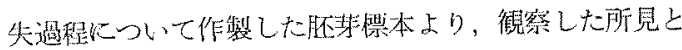

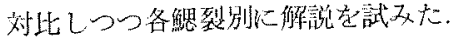


第 2 図

\begin{tabular}{|c|c|c|c|c|c|c|}
\hline $\begin{array}{l}\text { 脴 } \\
\text { 標 }\end{array}$ & $\begin{array}{l}\text { 倠 } \\
\text { 本 }\end{array}$ & 大きさ & 断 & 樋 & 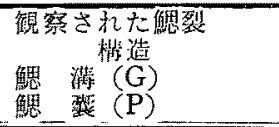 & その优の関俰ある維緎 \\
\hline & 1 & ${ }_{11 \sim 12 \mathrm{wk}}^{50 \mathrm{~mm}}$ & 矢 & 状 & $\begin{array}{ll}\text { ts } & L \\
\text { t } & L\end{array}$ & 外耳道上皮板 \\
\hline & 2 & ${ }_{7 \mathrm{wk}}^{17 \mathrm{~mm}}$ & 矢 & 状 & $\begin{array}{ll}\text { ts } & L \\
t s & L\end{array}$ & \\
\hline & 3 & $17 \mathrm{~mm}$ & 水 & 平 & L & $\begin{array}{l}\text { 二次性外畨道 } \\
\text { 取管 原 基 }\end{array}$ \\
\hline & 4 & $16 \mathrm{~mm}$ & 斜访 & & L & 妇状舌管 \\
\hline & 5 & $16 \mathrm{~mm}$ & 藏南 & 㨁 & 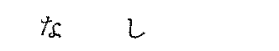 & 甲状舌管 \\
\hline & 6 & $10 \mathrm{~mm}$ & 水 & 平 & $\begin{array}{l}\mathrm{G} \\
\mathrm{P}\end{array}$ & \\
\hline & 7 & $12 \mathrm{~mm}$ & 水 & 5F & $\begin{array}{ll}\mathrm{G} & 1,3,4 \\
\mathrm{P} & 1 .\end{array}$ & \\
\hline & 8 & $8 \mathrm{~mm}$ & 水 & $3^{2}$ & $\begin{array}{l}1,2,3,4 \\
2, \\
\end{array}$ & Vesicle 4 \\
\hline & 9 & $9 \mathrm{~mm}$ & 矢 & w & $\mathrm{G} \quad 1,2,3,4$ & \\
\hline
\end{tabular}

第 4 節 鰓裂の発生上消失

\section{第 1 鰓裂}

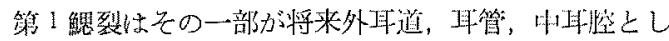
て発生して行く点で他の鰓裂と異る。第1触裂の外还葉 性部分である第 1 鳃溝は，発育の良い第 1 ，第 2 鿬弓間 に狭まれて肧芽側面から腹側正中面に问つて長く延び る. 消失の時期子他の鰓瑇心比し早期行われる(第 1 ， $4,5,6$ 㖤)

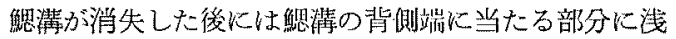
、陌凹部が残る(第7,8図)。

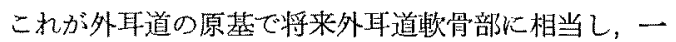

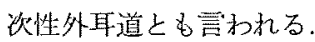

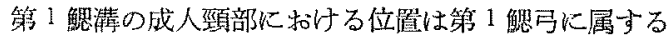
下鮳骨の下方で第2鰓引性の舌骨より上方にあり従つて 外耳道人口部と舌骨上縁を結ぶ線が歓辋に相当すると考 えられる(第9図).

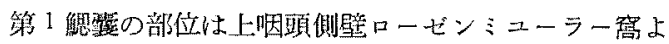

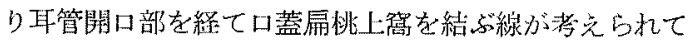
いる.

外耳道の発生の初期生肧势 $16 \mathrm{~mm}$ 位の頃，㕕く浅小 凹みであるが3ケ月頃になるとこの低部より上皮縕胞が 慗状に中耳宾に向つてのびる。これが外耳道上板で， やがて内腔が出来，骨性外耳道が出来る（第10.11図）。

耳管は第 1 鯰壁背側角の外方への陷凹部之して作られ

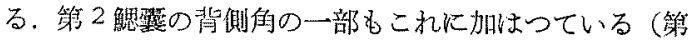
6,8 図)．耳管の先端は広がつて中耳腔の原基となり，

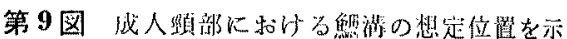
したもの.

Proctor ${ }^{12}$ が引解した Keith の発坐

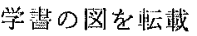

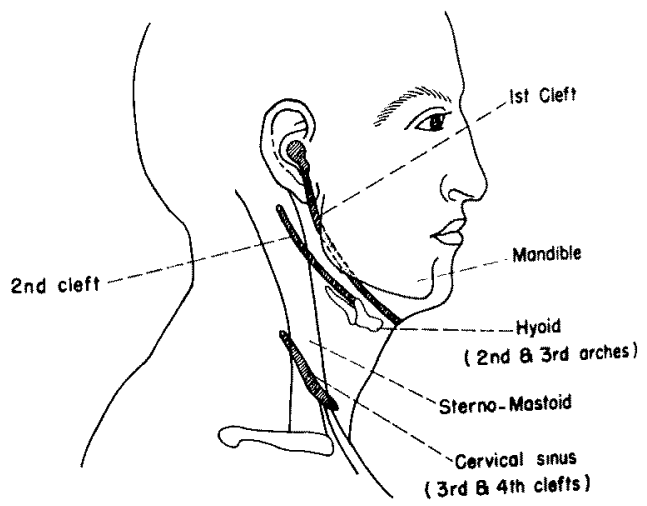

$50 \mathrm{~mm}$ の胎思においては外耳道上皮板と接近し䚳膜の 北成が胃られる(籁 10，11 図）。この特期には外耳は ぼ形成されている．鼓膜と閉鎖膜とは類似点はあるが同 一ではない、Wengelowski によれば，第1 解裂の閉鎖

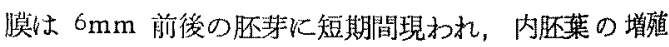
により稳速に失われる。この内肧葉にはメッケル軟骨， ライケルト呤四が含まれる。

Wengelowski は各解裂に拈ける閉鎖膜の形成支追求

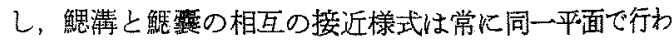
れず，相互に交义する翼る平面上にあり，双方がX字状 に交わる位埴にのみ閉鎖膜が形成されるとしだ。この観 


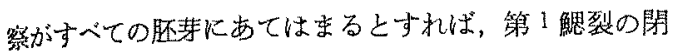

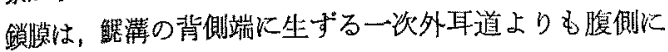

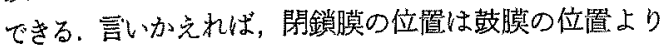
下方化ある。

Richard 5) は先天性外耳睮型の発生病理を研究し第 1 锞裂の閣鎖膜と鼓膜とは同一䇫所にない事を認めてい ๖.

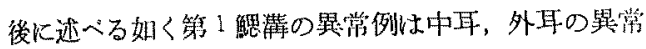

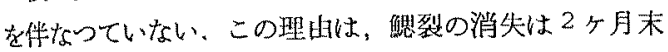

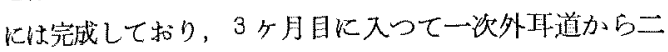
次性外耳道が生じ，耳介が形成され中耳内器管の分化が 始まるのであるから，この時期に生ずる中耳・外耳瞄型 とは時閪のずれがあるからと思われる。

\section{第 2 鰓裂及び形洞}

第 2 鳃弓以発育が良く毁蓋とも言われ鰓弓の尾端部は

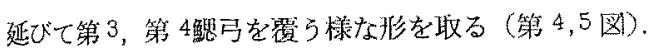

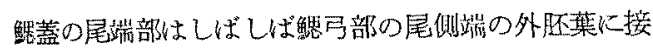
し，上皮性の洞を形成する，これが销洞でする（第2 図 C).

第2鰓清は一持期にはかなり樑くなるが，やがて完全 消失与る，第 2 鰓弓以下の外脴葉組織は相互に重なり 合つているため，鰓满の位算を想定することは困蜼であ るが，扁桃の頸部皮膚面相当部から吉骨部の間と考学ら れる(第9图)。

第2 鰓裂の留鑜膜は Wengelowski によれば，最も

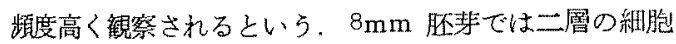

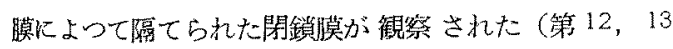
图)，ての位置は鳃瑇の潘ほ中央部にあるとされている。

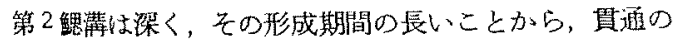
可能性も他の鳃裂閉錤膜に比い多いと想像される。

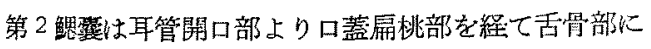
至るとされる，鳃翼の背側角は耳管の形成に参加してい る，その腹側角から口蓋扁桃が発生する，㦿桃の上皮は

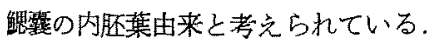

莖洞は6〜7週の闑にでき7週の終りには消失する. 第 $2,3,4$ の鳃㩐はこの洞状構造内に含まれる. 頸洞が外

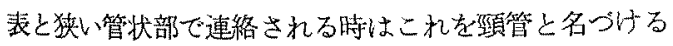
(第 2 图)。

Wengelowski は頸洞壁と胸腺咽頭管との近接関係を 重視している.

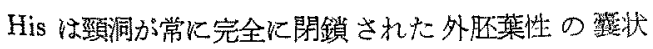
搆造を取ると考え，この組織の遗残が做頸部装蕾の成因 であるとした，しかし Wengelowski はこの遗残説に

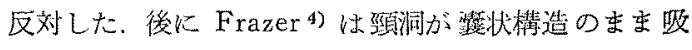
収されるのでなく，再び外表に開き，頸润内に包含され

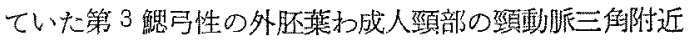

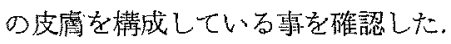

第 3 鰓裂

鰓拲は頸洞に含まれて，项管を経て頸部表面に開く、そ

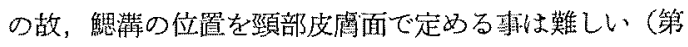
$4,5,6$ 国)

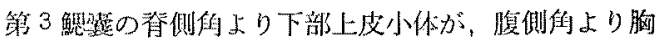

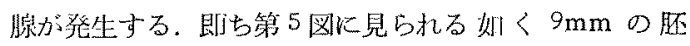

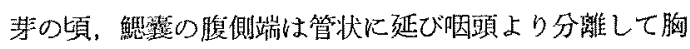

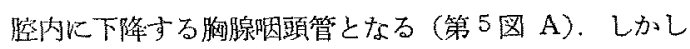
この時期の肧芽は第3 鰓琵と胸腔との距離は極めて接近 して和り胸腺咽頭管の实際の移動距離は数ミリメートル

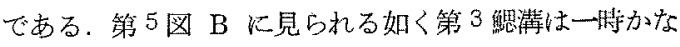
り深くなるが䎅鎖膜の形成頻度は低いと言われる。

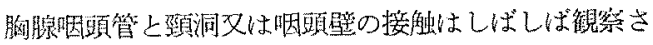
れ Wengelowski は頸瘦の成因がこの雨者の接触点で 二次的に貫通する場合に如るとした。

第 4 鰃裂

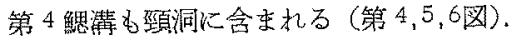

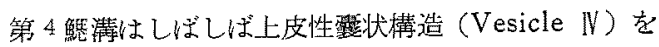
作ることをGarret6) が報告 したが，これは著者例の $8 \mathrm{~mm}$ 肧芽比和いて見られた（第 4 图）。

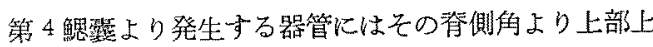
皮小体，腹側庙より胸腺の一部がある，第 4 鰓要索の成人

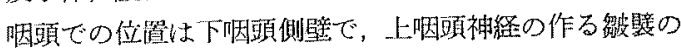
下张あるとされ，開四部があれば梨子状筒から食道入 口部にかけてとされている。

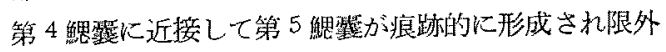

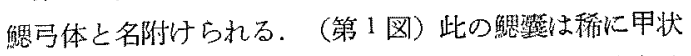
腺組織内の裂腫として出現することるあるが臨床的意義 仿ない。

\section{第 2 章 病因諭に関する歴史的考察及び現況}

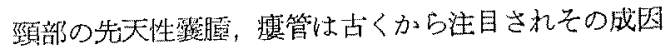
に関して多くの学説が出されたこれ等の諸学說の中，

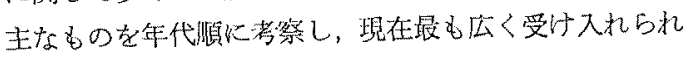
ている病因説について述べて見た。

第 1 節 歴乐的背景

1. 鰓性器管の発見上鰓性器管由来説

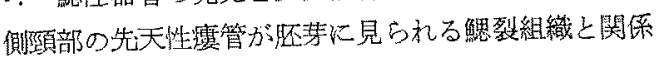
あることを最初に称えのたは Ascherson (1832) であ つた. Ascherson は Rathke (1825) がブタの肧帮で, 


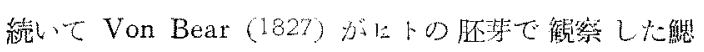

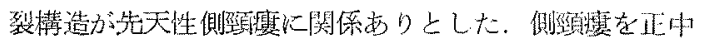

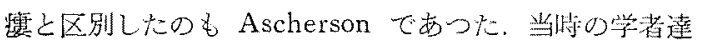

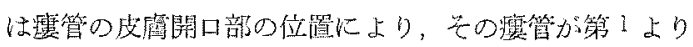
第4の魹裂のいつ机属するかて決めることができると 若觉た。

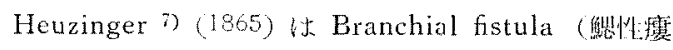

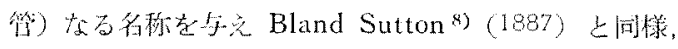

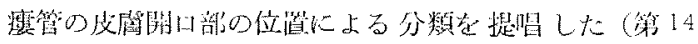
(ख).

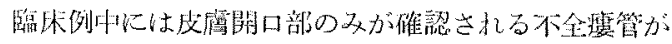
少なからず見ら机るのでこのような分類もやしを得ない ものであつた、しかし進管は下葝部に開口するものが多

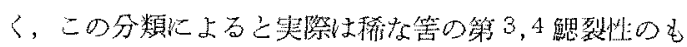

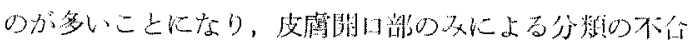

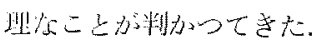

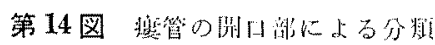

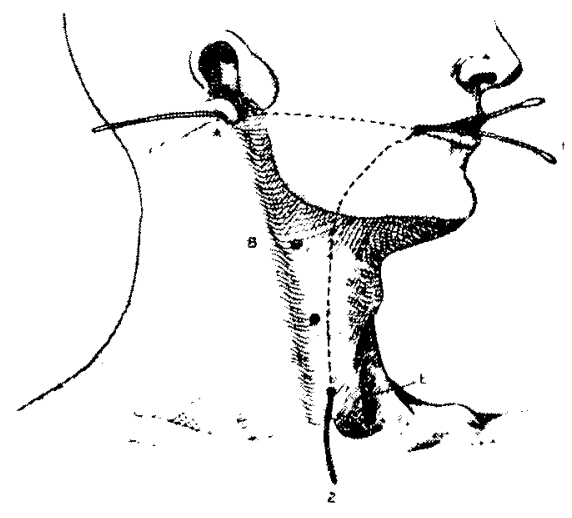

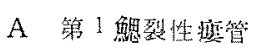

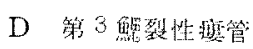

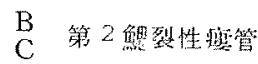

Arey, L.B. "Developmental Anatomy" W.B. Saunders Co. (1954) \&り

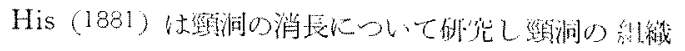

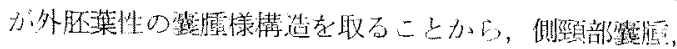

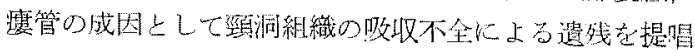

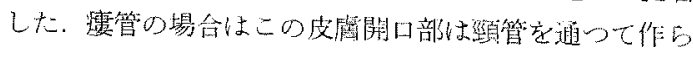

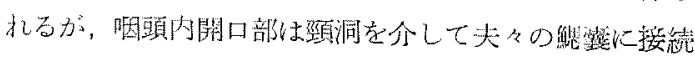

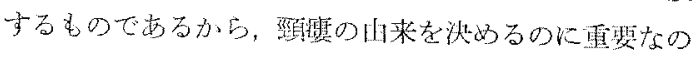

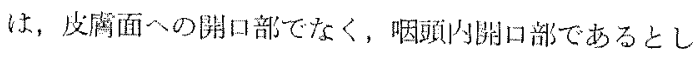

t.

Rabl 9) (1886) は上トの肧芽で閉鎖膜を観察し，この 開鐄膜の第孔があり，それが成人の頸部に遗牫していれ ば先天性完全瀼管の原因となり得ることを報告した。

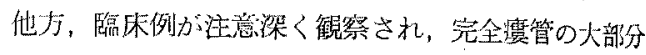
が口蓋留桃附近に认開口部を有することが明らか心さ

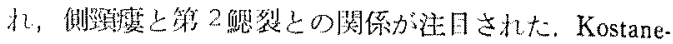

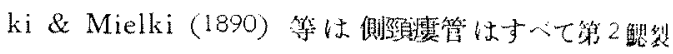
に山来すると主偯した。

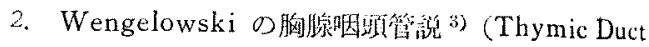
Theory)

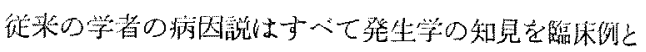
関係づけて，この先天性聅患の成因を説明しょとしたも

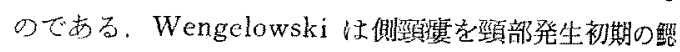

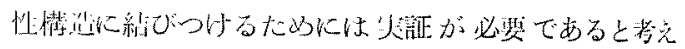
ז.

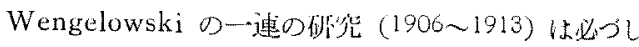

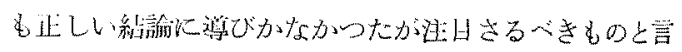

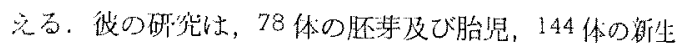

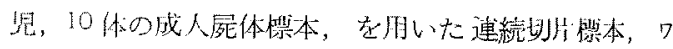

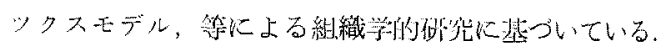

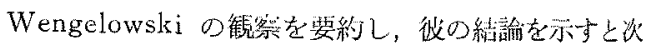
の外くになる。

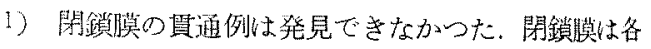

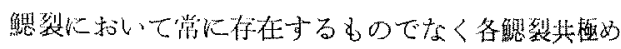

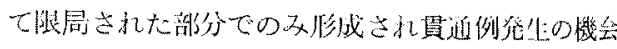

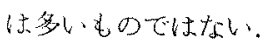

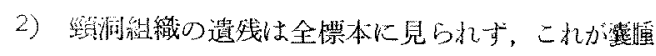
の原因と成り得ないと結論した。

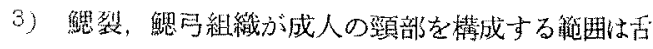

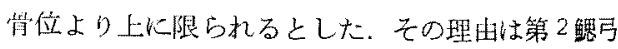

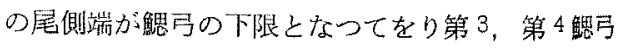

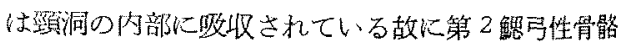

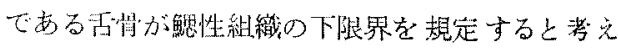

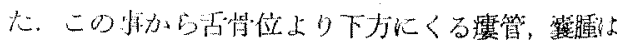

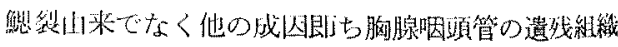

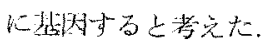

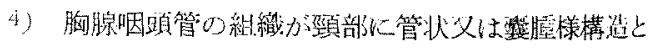
して遗残している例在成人腮部で10体中2体见， 新生胃 65 体中 21 体に認めることができた。以上

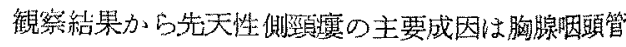
の遗戏によると結諭した。

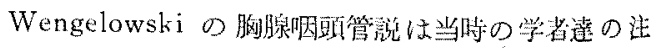


目を集め Mayer 9等の支持を受けたが反刘する学者子 あつた。 しかし Wengelowski の学説にはいくつかの 誤りがある，その主な点は彼は解性遛残組織が含骨位上 り下方現われることはないと信じ郚床例の説明には細 烈以外の原因を考えようとしそれを胸腺咽頭管に求めた こと. 彼は胎児と成人ではその頸部組織の前後，上下の 阙係が著しく黑るため鮊性䋖織の下限界をきめることが

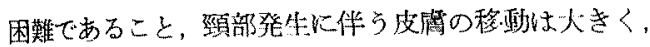

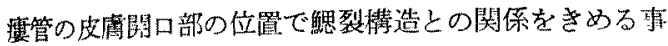
は意味がないことを理解できなかつたことにある。

Wengelowski の舊察した胎紧標本は数の上では多い

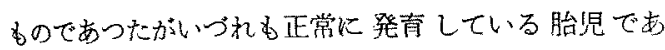
り，先机等の所見から発生異常に上る渏型についての成

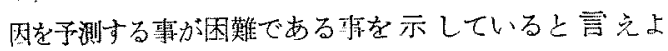
5 .

\section{Frazer の側頸部遗残組簐由来説}

Frazer 4) (1940) 位頸部の留性器管の発生に関して公

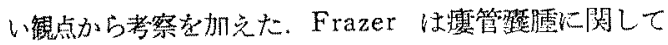
從来の等者が取つてきた栏な，第２鰓裂，若しくは胸腺

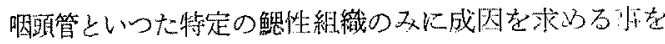

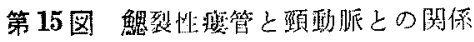

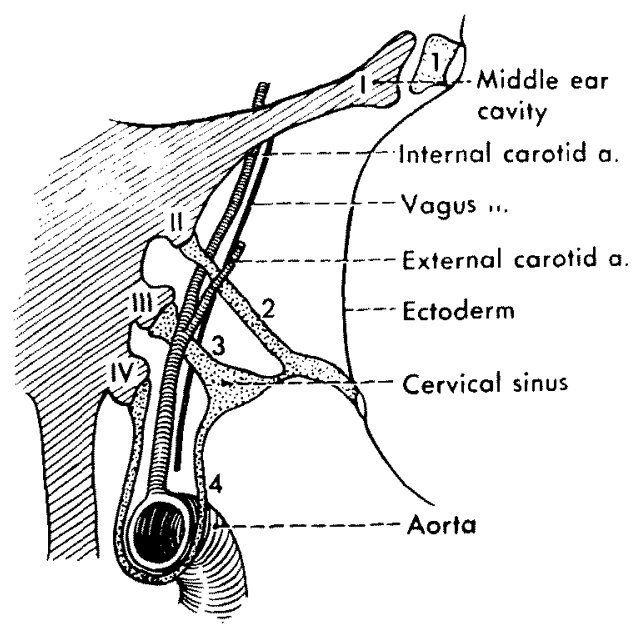

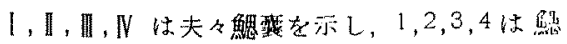
淎由来の旗管を示す。

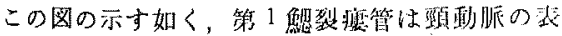
㞗を

第 1 䱊裂性は内外頸動脈の後を

第了触裂性は総澒動脈の後を

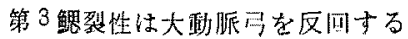

Frazer 4) より聜轴

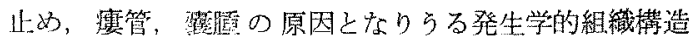

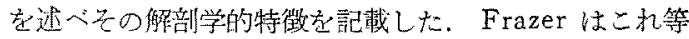

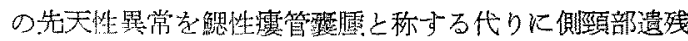

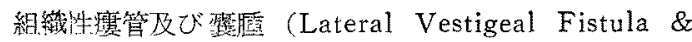
Cyst）の名称が適切であるとした。

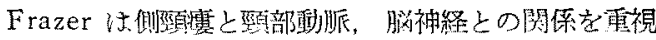

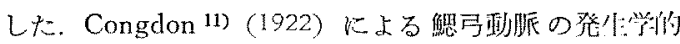

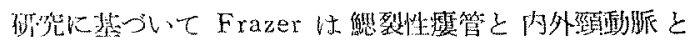
の闑係がかなり固定したものであることを明らかした

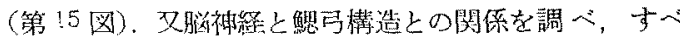

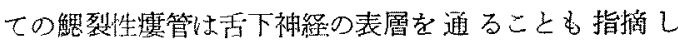
た. Frazer の観察によれは頸同は簬状に閍鎖されたま

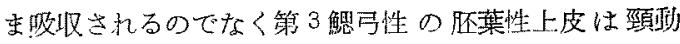

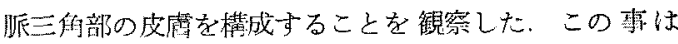
Wengelowski が鰓马明来䋎織は舌骨位より上部に限定

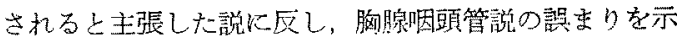
するのであつた。

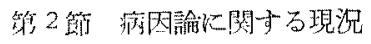

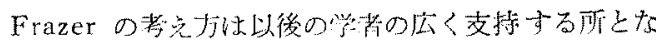
D. Proctor 12) (1955), Lyall \& Stahl 14) (1956), Millar ${ }^{13)}$ (1958) 等出いつれれ Wengelowski の胸腺 咽顽管説の誤まりを指摘し Frazer と同じ立㘯を取つて いる．発生学の立場から側頸部の胎生期組織の中で艺の

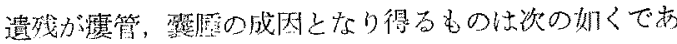
3.

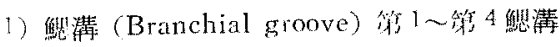

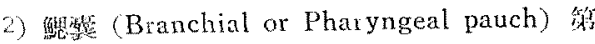
$1 \sim$ 第 4 労思磷

3) 盍洞

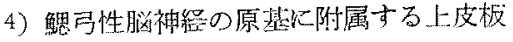

5) 舅㩐由来の上皮板嫼栕

6) 胸腺咽頭管

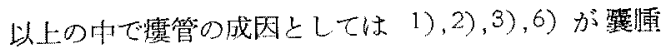
の成因としてはすベてが考へられる。

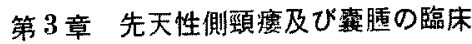

第 1 節 文献的考察及び総論

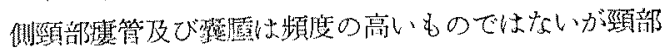

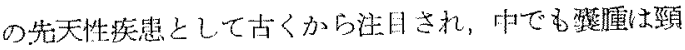

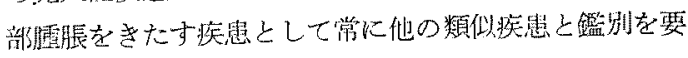
ナるむのとされてきた。

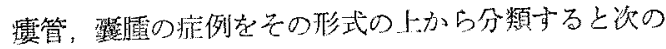
如くなる。

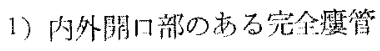


2) 皮勴開口部のみるる不完全瘦管

3) 咽頭内開口部のみある不完全猄管

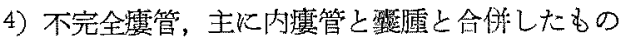

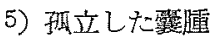

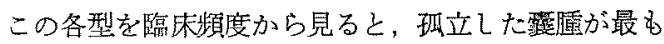
多く，次いで皮膚開口部のある不全虔管が多く，頻度が 下つて完全漒管及び内開口部を有す不全瀼管の順になつ ている 15).

臨本報告例の数は内外の文献で見るとかなりの数にの ぼる。本邦例では1926年以降の症例定武田 ${ }^{16}$ (1955)及 び大田 ${ }^{17)}$ (1963) が総括しているがその後の例も含め

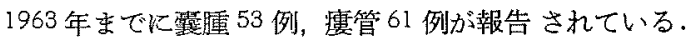
外国の支献では Miller (1958) の集計報告の他に個々 に多数症列を挙げている文献に Pemberton ${ }^{18)}$, (319 例), Hyndman \& Light ${ }^{22}$ (90例), Ladd \& Cross $^{1 i)}$ (83 例)，Lyall \& Stahl ${ }^{14)}$ (57 例) 等がある。

これ等の報告例の内容を先にのへた各型分類して見ると

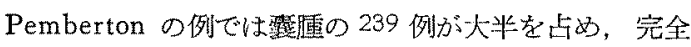
瘦管 31 例，皮虚開口部のある瘦管 30 例，咽頭内に開口 するもの9例となつている. Lyall \& Stahl の例では

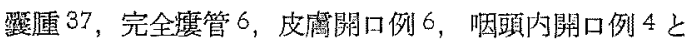
なつている。

瘻 管

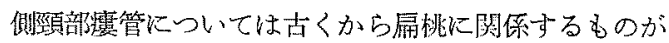

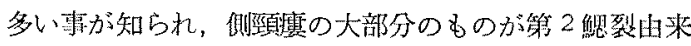
である事が定説になってきた，しかし他の触裂性のるの 特に第 1 鮊裂由来の筫管の報告例 b最近增えてきた。

瘦管の成因を各種の钼部遗残組織に対比させ，そのい、 づれに由来するかを決める事は必つしも容易ではない. 完全瘦管の場合は比較的簡単ではあるが，不全形の瘻管 は, 周囲組織上の解剖学的関保, 組織所見上り推定する 本が必要となる。

成因波定の上に参考となるるのは，Frazer も述べた 如く，咽頭内開口部の位置，頸動脈との閔佰，及び神 释, 觔との解剖学的関係がこの順位の信頼度できめ手と

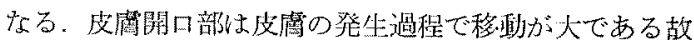
きめてになり難いことが学晢の一都した結論である。

灌管の成因を調ベる上に皮第若しくは胭頭内開口部が 先天的のものか後天的のものかを注意して見る必要があ

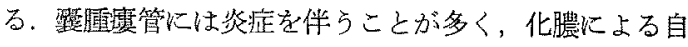

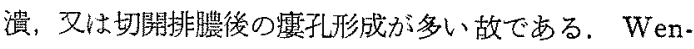
gelowski の胚腺胭頭管説では皮膚開口部はすべて後天 的なものであると考えた，この説は事实に相遠するが，
二次的锶孔形成は頻度の低いるのではない，

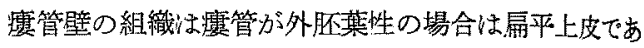

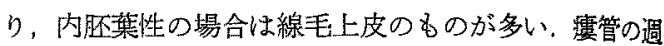

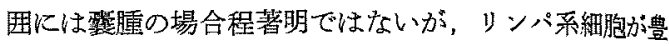

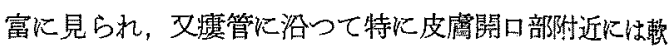
骨，筋肉組織が見られる㱏例がある。

\section{露蕾}

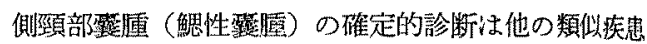
からの除外法に依つて行われる。

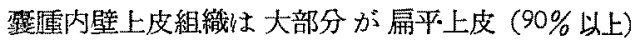
で線毛上皮性のものは少ない。

Bailey ${ }^{20)}$ は側頸聚䐦を 1 型より4 型に分類した（第 16 図)。この分類は水平断面に水ける頸部臟器 との位眉 関係に基づくるのである.

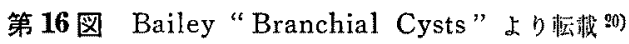
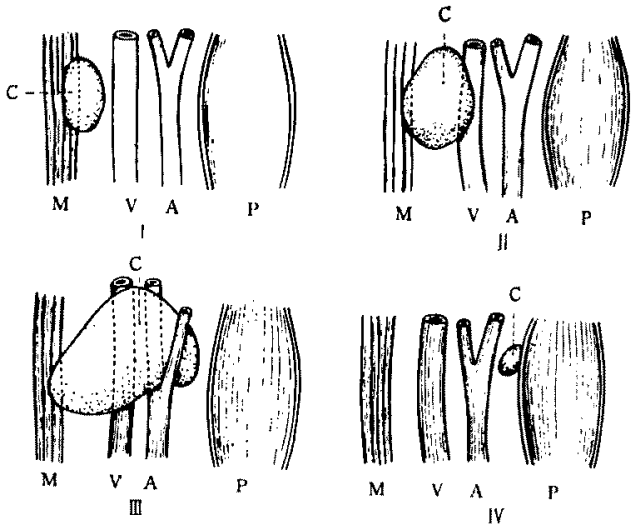

M 筋肉 (広沟筋他)

A 頙動脈

$\mathrm{V}$ 静眽

$\mathrm{P}$ 咽磌

鰓性整腫の頸部組織との位置関倸を示す

坬立性嫼腫の鰓裂由来を決める事は容易ではない，垔盾 の現われる位置からある程度推定可能なものとして，耳 下腺下部に見られる垔第尰 1 鰓裂性，Bailayの第3 瑟の如く頸動脈分岐部にまたがるすのは第2 鲤裂性，霍

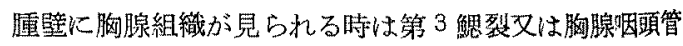
由来と推定可能のものもあるがこれ等は例外的であ万 5 .

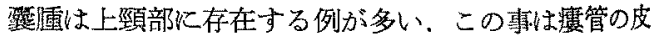
閣開口部がしばしば下頸部に見られる事と対照的であ る. Proctor ${ }^{12)}$ はこの理由として頸部の発育に伴つて 鰓裂性外肧葉組織は大さく下方に移動し，この為わ皮着 面に開口する瘦管は下方に延長されるが，皮虞に固定さ 


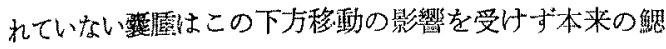
马絪絊領城である上頸部に存在するのだと説明してい る.

霆繮の週围には例外なく豊富なりンパ性細胞が見られ る、Wengelowski はこれ等が胸腺に时来与る細胞と考 えた.このリンパ性細胞の由来に関しては明確な説明が なく，後述ベるリンパ節队上皮迷入䛠の出される原因 となってい.

霍腫は生後長期間にわたつて自覚されず，成年期以後 に腫脹して自賞され，又咽䫒内に直接連絡していなくて も上気道炎症後に炎症症状を呈してくることるある。

Bhasher \& Bernier ${ }^{21)}$ は 側頸部上皮性整蕾をその

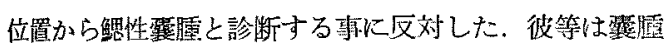

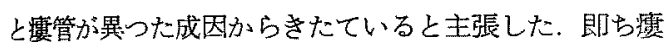
管と異り慗堙は常に週团にリンパ組織を伴つて居り、こ のリンパ紐胞群は多くリンバ節の權造を取つていると考

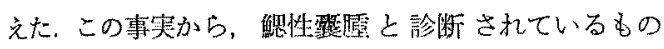

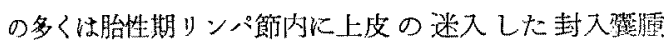
(Inclusion Cyst) であるとの説を出し，これが，耳下

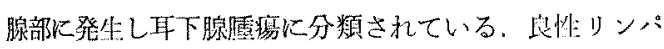
性上皮䐺 (Benign Lymphoepithelial Lesion) と网一 のものと考えた。

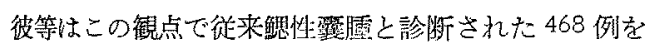

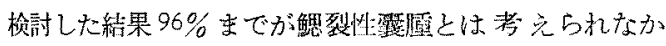

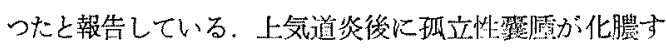

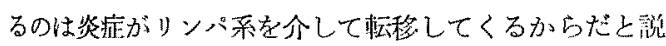

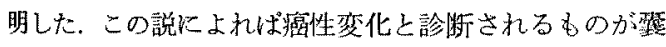
腫に多く，踖管に見られる事の極めて稀である事が説明 しやすい.

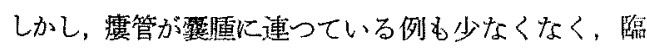

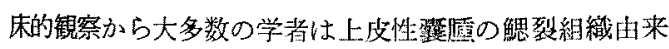
説索支持している。

掼管及び整蕾の発生頻度には性別左右別に差がないと

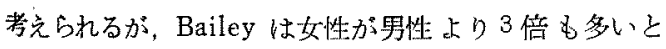

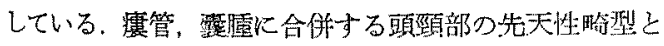
して耳前瘦管が時々見られる。

\section{第 2 節 各詥}

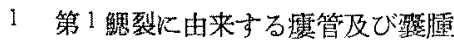

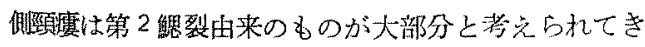

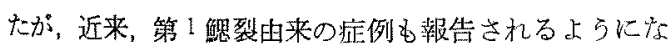

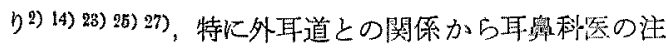
目岂れる所となつている。

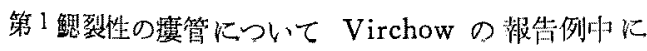

完全掼管例が記载されていると需われるが (14图 A) 明らかでなく，Frazer に上る記载が，最初と考える人

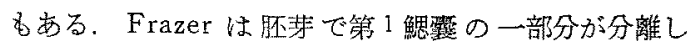
て㱋状棈造を取ることを観察し，この組織が遗残して第

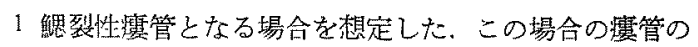

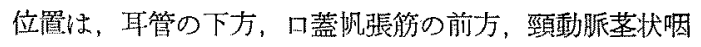
頍の表層にあり，咽頭内開口部はモルガ二氏洞であるう と述べた，しかし，報告された噪床例には，かかる内胚 葉性の瘦管例小たく，教告例は全例が外脴萁性不全掼管 である。

内外の文献を見ると現在までに約 30 例が 報告されて

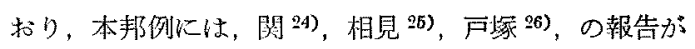
ある。

完全㿉管の極めて稀な理由の一つとして Wengelo-

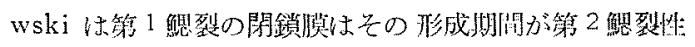
閒鑟に比し短い牙青举げている.

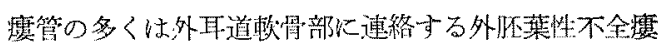

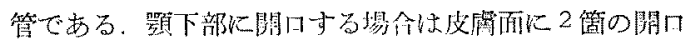
街家持つ椟管となる。

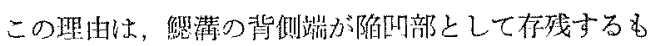

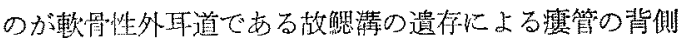
端が外耳道に連なつていることは容易に理解できる。

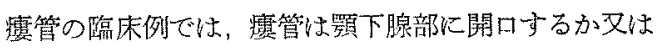

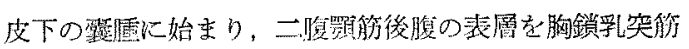

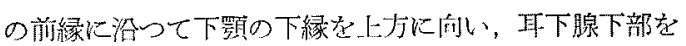

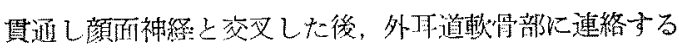
形学取名。

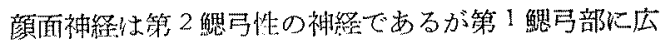
か゚る顔面筋老支配するため，瘦管は顔面神経の主幹と交

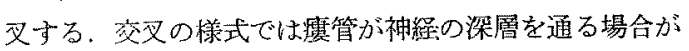
多い. Work \& Proctor ${ }^{27)}$ は瘦管が神経献を貫通して いる例を報告している。

瘦管が外耳道に閒口する場合，耳漏が症状の一つとな り慢性外耳炎㕛は慢性中耳炎との鑑別を裂する。瘦管の

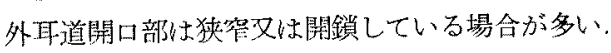

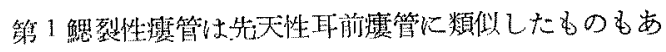

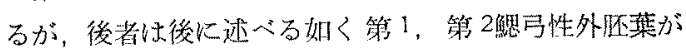
外耳支形成する際に生ずる融合不全が原园であり鰓裂性 教管とは区別される。

濩管の多くは外耳道軟骨に移行する軟骨組織を゙篹管の 周困に有している，㢞管が中耳腔に直接連絡していたと 垠告している Druss ${ }^{28)}$ ，関 24）の例は他の症例と活ぼ類

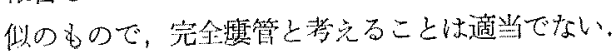




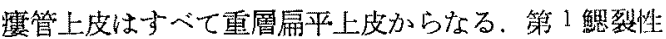

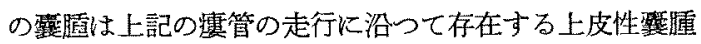

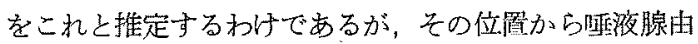
来の嵲腫と鑑別する必要がある.

Hoffman ${ }^{29)}$, Sobieski 30) 等は耳下腺内又红耳下腺下

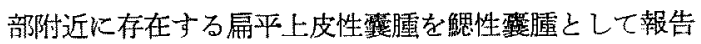
している.

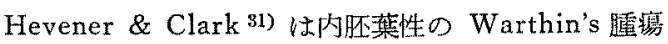
(Cystoadenoma Lymphomatosum) b文内胀葉性の鰓

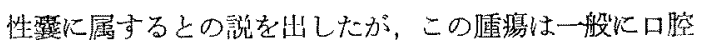
内上皮の耳下腺内リンパ組織に迷入したものと考克られ 鰓性覆腫から除外している。

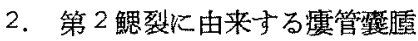

この群蕾する例は他の鰓裂由来のむのに比し圧倒的 に多い.

完全櫋管例の報告されているのは第 2 鰓裂についての みである，竹田，大田の本邦総括例の中でる扁桃に関係 ありと診断された㿉管が 61 例中 14 例あつたと報告して いることでもわかる。

第 2 鰓裂に庵管が発生し易い理星は不明であるが，完 全瘦管の多いのは Wengelowski の䘽察に上れば第 2 鰓溝が樑く，閉鑜膜の形成頻度が高く，鰓裂持続期間が 長いことが認められているが，このよらな条件の複合に よると思われる。

完全㾇管の多〈は頸部下方の胸鎖乳突筫の前緑に当心 る皮腐開口部に始まり，広頸筋を貫通し胸鎖孚( 突筋の前 緑に沿つて上行し，舌骨大觕部で内方に问い，内外頚期 脈の間を通り斜上方に向い，颚 2 腹筋の下方で中晒頭方

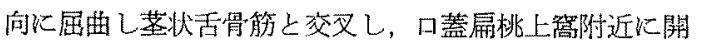
口する，不全震管の場合でもほぼ上記の走行を取る。

Frazer は各鰓裂性の瘦管の走行と頸動脈との関係が 固定したものと考えた（第 15 図）.

Frazer 快第 2 鰓裂性惯管は例外なく内外頸動脈の中 間を通ると考兄た。この関係は臨林的にあてはまる場合 が多い：乙かし例外もあり Himmalstein ${ }^{32)}$ は外頸動 脈の表層を通る第 2 解裂性の完全瘦管の自験例を示し， 頸動脈々耧管の発生時期の㭙問的ずれが，両者の解剖的 関係に変化をきたすであろらとして頸動脈之㿉管との関 係を絶対的なるのとすることに反刘している，組織学的 に見ると實管は外阫葉性の扁平上皮又は内肧葉性の乎吸 上皮からなり，臨床例では屚平上皮性のものが多い， 完全㿉管では上記の 2 種の上皮が連續している例も報告 されている。

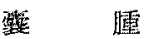

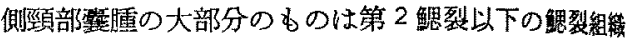

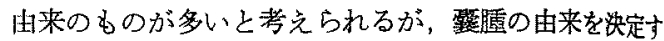
る事は難加しい，第 2 鰓裂由来と思われるのは Bailay 20）の分類中の第 3 型（第 16 図）である.

策 2 鰓裂性瘦管の摘出術式に関しては症例方比較的多 いため記載が多い10１2)。皮下の浅在性瘦管の部分飞対 しては，時に階段法 ${ }^{33}$ ) (ladder step method) 澥い

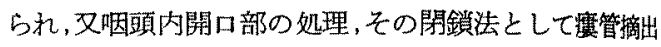
後に扁桃窝内に断端を内反する術式が用いられている。

3 . 第 3 ，第 4 触裂の異常

側頸瘦及び麗腫の中でこの鮊裂に属することの明確な 症例は少ない。

Wengelowski の胸腺咽頭管説によれば庫管，漖腫の 大部分のものが第 3 鰓㴾由来の胸腺咽頭管の遺残による とするものであつたが，その後の研究で Wengelowski 説の譟りが指摘され，この群つ症例の少ない事が多くの 学者の一致した意見とないている。

第 3 鰓裂性瘦管の胭頭内開口部は下咽頭側壁又は梨子 状窝で，上咽頭神経の主幹よりも上にあり又，第 4 蟹裂

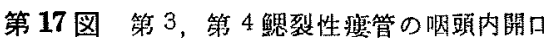
部を示す

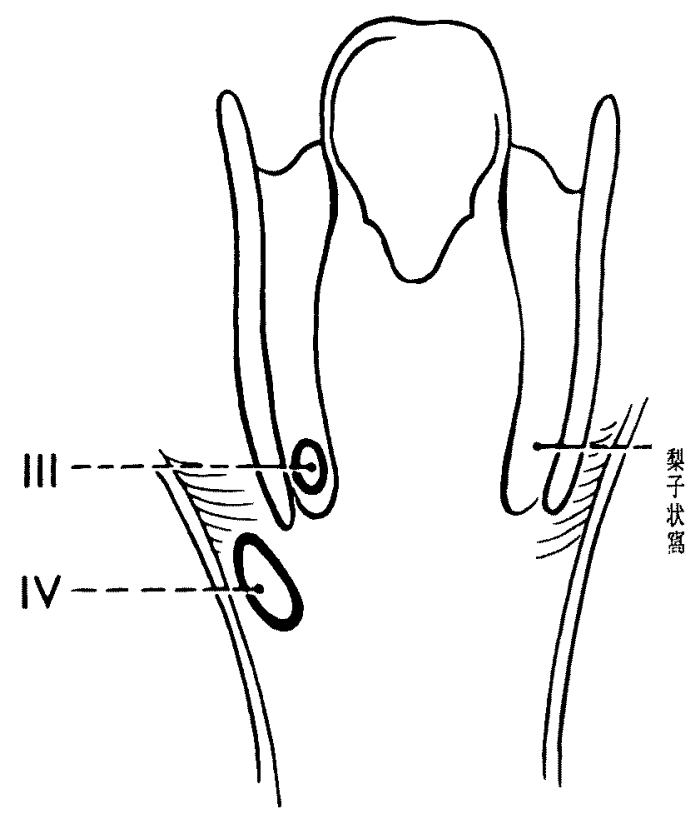

第 3 鰓裂（III）は梨子状窝 筙 4 鰓裂（N） は食道入口部 
教管の予想される咽頭内開口部はこの神経より下方，即 ち梨子状管又は食道入口部とされている(第17図).

完全霬管の場合の程路は，第 3 鰓裂性のものでは舌骨 甲状膜の側面を貫通し，直角に下方に屈曲し総㥧動脈の 後方を通り舌下神経の表層を交攴し下頸部に開口する。

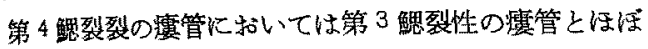

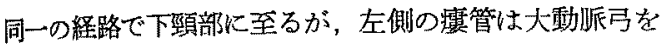
後方より反回し，右側で㥽骨下動眽を反回した後に， 鎖骨上部の皮碚面に開口すると考えられている。

しかし，第 3 ，第 4 鰓裂性の完全㿉管の症例は報告さ れていない.

完全㿉管の見られない理由として Wengelowski は 彼の観察した肧芽ではこれ等の鰓裂の閉鎖膜はその構造 及び頻度から考元て貫通する可能性の少ないことを挙げ ている.

Raven ${ }^{40)}$ によれば，この瘻管は共に鰓性器管領域よ り尾睢に発生して頍部に移動する舌下神経と交刃するこ とが必要であり，この种経が㾇管を遮訴するためである らと想像している。

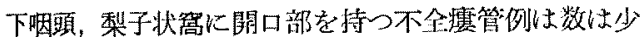
ないが報告例がある，本邦例では著者例 ${ }^{34} の$ 他に，執

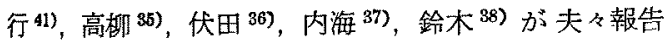
しているが詩細は不明である。

広戸 ${ }^{39)}$ は皮筬開口部を有する浅在性の不全瘻管で先 の方向から第 4 鳃裂に属すると推定される例を赫告して いるがこれる確定的でない，Raven は下㸶頍・食道入

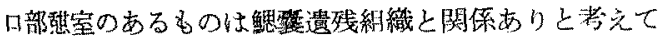
拈り，後述する著者例るこれと関保がある。

裂踵でこの鮸裂に由来するものは診昕が難しい。 Lyall \& Stahl 43) 仕梨子状䆞に密着している禁蕾を第 3 愳裂のものと報告し，執行 ${ }^{41)}$ は胸腺組織が見られる

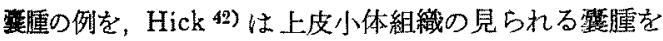
報告しているがこれ等は第 3 ，第 4 触裂性の 㕛は胸腺咽

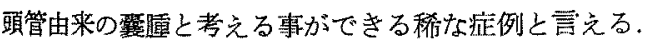

Frazer の指摘した頸部胎性期遗牫組織の中緦裂以外 の組織由来の露腫は報告例が見られない。

第3 節 舆味ある自験例

先にも述へた如く側頸瘦の中で第 2 鳃裂性の瘦管は報 告例が多く，その踇床像は教科書にも記载されているが その他の鳃裂由来のbのは報告例が少ない，

この項では著者の経験した第 1 ，及び第3鰓裂性の雯 管についてのベる。

症例 1。患者は 25 才の男子で左顎下部の腫脹を主訴
として昭和 32 年 7月, 聖路加国際病院耳鼻科に来院.

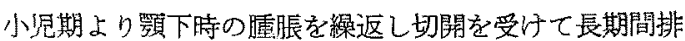
膿を見たことがある，左外耳道は常に湿潤を自覚，耳下 部を圧迫寸ると外耳道内心獎液分泌を見ることがあつ た．来院時所見では，左顎下部に瘇脹あり，その中央部 に洀痕性楩山があるが瘦孔は認るられなかつた。（第 18

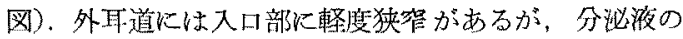

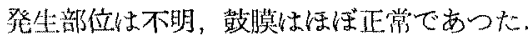

磌下腫脹部を切閶して見ると，訾计と共に多量の皮脂 様内容物が排出さ饥た。内容除去後造影剂注入により外 耳道に連絡する瘦管の存在が確立した（第 19 図），瘻管 の外耳道開口部は極めて小さいものであつた。

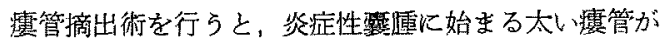

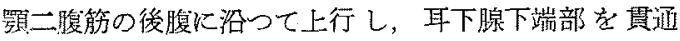
し，顔面神経主幹の樑層を通り外耳道軟骨部に接続して

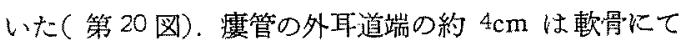

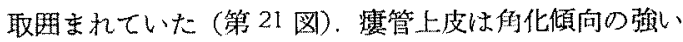
重層噉平上皮でつあた。

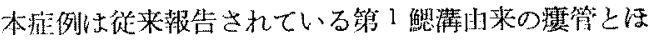

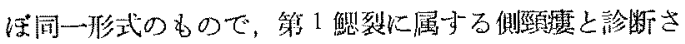
れる。

症例 2。患者は22才の女子，左側頸部の瘦孔を主訴 として昭和 33 年 10 月聖路加国際病院耳鼻移に来院. 孚 児期に短期䦌左頸部薑脹を見た病歴があり，当時某大学

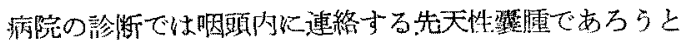

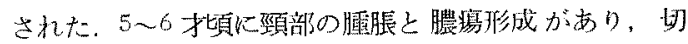

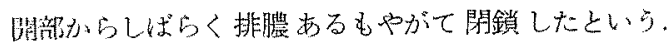

以後無症状。来院3 週間前よりカゼに引続いてて鰂部蕾 脹，自清排膿があり，瘦孔索形成し睡液又心液体食物が

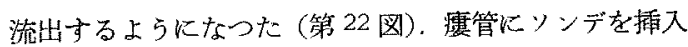
して見るとその先端は梨子状裔下端に接しており（第23 图），バリウム燕下による下咽頭造影では下䀠頭側壁に

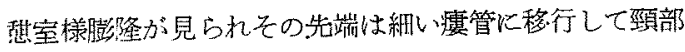

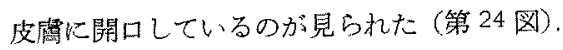

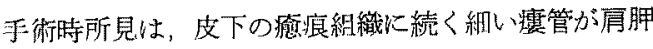
舌骨筋の上部で胸鎖乳突䍉の前縁から媣部に向い, 総頸 動眽の表面を棈切つて甲状軟骨の側方から咽頭側壁に

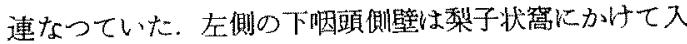
口部の広い紡鍕状の喤室様膨大を示し瘦管に連なつてい た。組緎検查では喤室様部は正常の㧢頭粘膜であるが虂 管部は線毛上皮からなり，周团に多数のリンパ系細胞が 見られた（第 25 图）、㾇管の皮咸開口部咑近は资症のた め上皮住損していた。 


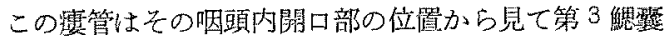
由来のものと推定される. 元来は不全瘦管であつたもの が炎症のため皮膚面に開口したものと考兄られる。頸動

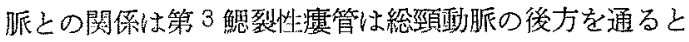
されている理論的位置とは一致しないがこの関係は元来 完全度管の場合にあてはまるもので，不全瘦管の場会，

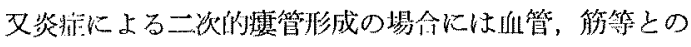

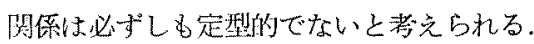

咽頭菂室の合㴊した成因については，Raven は先天 性下咽頭，食道喤公の成因の一つに鰓裂異常をあげてい

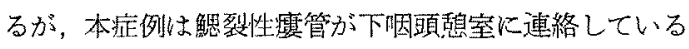
点で興味のある症例である。

\section{第 4 章 関係疾患及び鑑別を要する疾患}

籍 1 節 阙係疾患

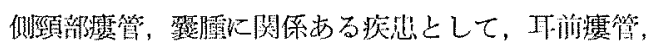

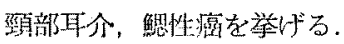

1) 耳前瘦管

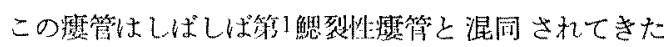
がその成网に沶いて異石故区別する必要がある。即ち耳

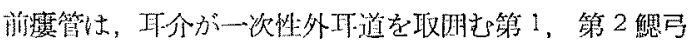
の外肧宾から形成される際化介の各部を作る外肧葉性 原基の融合不全が生じ上皮が皮下に塄没されて霓管が生 ずる(第26四)、しばしば炎症を伴い手術的治寮の対象

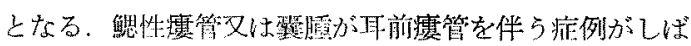

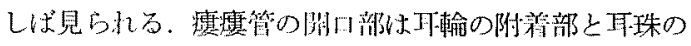
间に多い。

2) 頸部耳介

頸部に副耳様皮虐附属物を見る事がある（第28図）. この形は棒状の単純なものから耳炏やや類似するるの まであり，皮下般骨を有する例もある，耳介性元来，

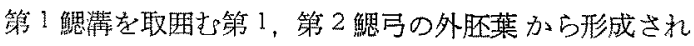
るものであり，これから類推して頸部耳介の成因は第 2 又は第 3 鰓溝を取囲を第 2,3,4 の中いられかの鰓亏性外 肧葉の異常に上ると思われる。

3) 鰓 性: 癌

Von Volkman 44)（1882）は頸部皮下に原発したと

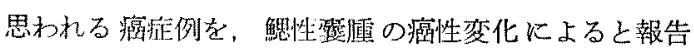

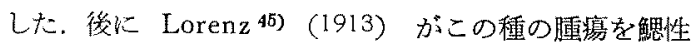
癌 (Branchiogenic Cancer) と名附け大。.以来鯰性癌 の診制名のるとに報告される症例が多くなつた。しか

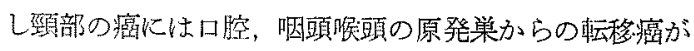
大部分であり，この中《は原発巣の発見の難しいものも

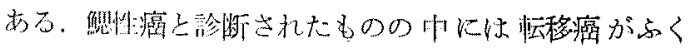

まれている事に注意する必要がある。この事は古く性 Bland Sutton ${ }^{8)}$ (1887), 最近では, Martin ${ }^{46)}$ (1948) が警告し鳃性癌の診断名をたやすく与古ることに強く反 対している.

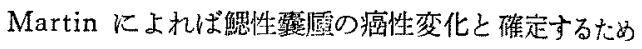

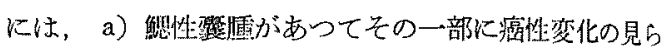
れるもの，b）この癌堙擜出後 5年以上他の部位湟発 栄が発見されない時に限られるとした。 Martin は今 まで賏性癌として報告された250 例を上記の条件下に

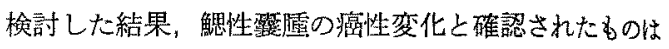
3例の及であつたと言つている. しかし一方，Ward \& Hendrick 2)（1958）壮 70 例の鰓裂性器管の異常例の中

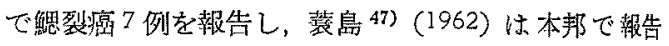

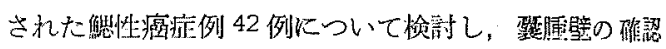
された例が 12 例あつたと郝告している。

同じ論文の中で筡島は鰓性癌には鰓管原性上皮茅より 発生する原発性畋性癌と覆蕾の癌性化の二種があるとし

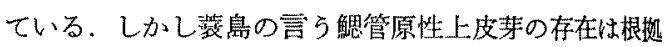
が弱いと思われる。.Bahsker 等は，頸部りンバ飾に上

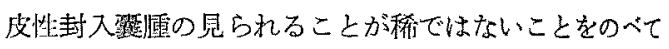

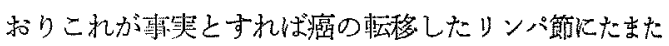

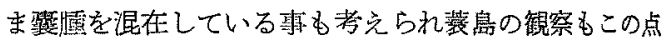
老考慮する必要があ万う。

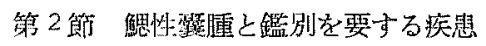

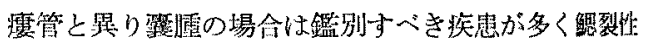

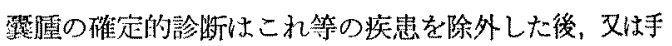
術摘出に上る組䄉検查に上つて始めて可能となる。

その疾患を列記すれば以下の如くである。

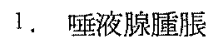

顎下腺，耳下腺下部の喠石，炏症，瞋瑒

2. 頸部リンパ節炎症

3. リンパ節隀瘍

恶性リンパ腫, ホジキン氏病、リンパ肉胿

4. 忶移性癌

5. 頸動脈球腫瘍

6. 甲状舌管腫，正中線に多いが洔に側頸部にある

7. 甲状腺腫

8. 神経線維腫

9. 脂肪腫

10. リンパ管霾 (Cystic Hygroma)，血管盾

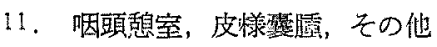

総括

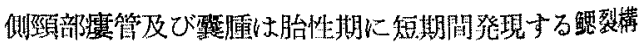


造の遺践背由来する先天性疾患と考えられているが，こ 记等の疾患の正しい診断と治療のためには，臨床上に見 られる疾患の諸相を䱒裂組織の発生学的知見と対比させ て考察することが必要と思われる。

著者は先つ肧茅, 胎児 9 個の標本につき連続切片標本 を作製し，これとより鰓裂構造の発生と消失過程を観察

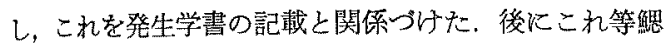
裂が成人の頸部汇遗残する場合の位置及び周团組織との 関係在推定した，次に本疾患の病因説阔関する歴史的考 察它行つた．古くから鰓裂に関係ある事は知られていた が、これを実証しょらとした Wengelowski は胸腺㸶

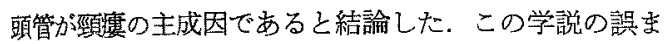
りは Frazer 以後の学者により訂正され，現在ではこの 疢喼怯特定の鰓裂組織のみに由来するのではなく瘦管や 露重の成因となり得る胎性組織はいくつかすり，臨床例 は夫々について発生学の知識炕基ついて成因を推定する ことが妥当であると考克られる。この際，咽頭内開口部 の位置，頸動脈，神経，筋肉との関係，組蟣所見がその 成因堂推定するのに役立つ。

以上の考点から䠛床例を文献上から分類し，興味ある

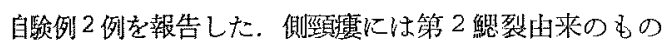
が多いため，従来すべてが第 2 鰓裂性と考光られてきた が，その他の䥺裂由来のものも少なくない，その中でも

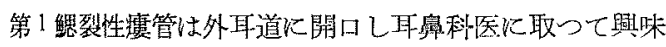

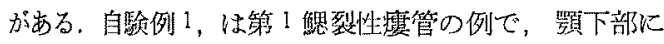
始まり耳下腺を貫通して外耳道軟骬部に連絡していた。 この瘦管恃外耳道内に排朖をきたし慢性中耳炎之の鑑別 安要する。第 3，4 鳃裂性㺏管の報告例は稀ではあるが，

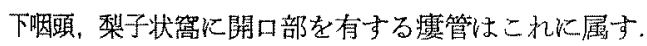

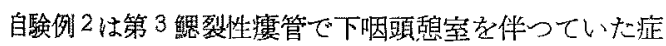
例である，側頸部の鰓裂由来の垔霆は豊富なリンパ組織 を伴っているのが特倣で，頸部の類似疾患との鑑別が必 要となる。

成因をやや異にするが関係ある疾患とのて耳前摟管",

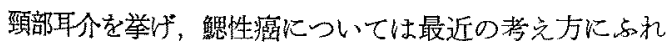

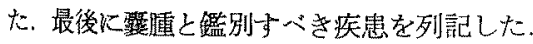

\section{文献}

1) Ward, G.E. \& Hendrick, J.W.: Diagnosis and Treatment of Tumour of the Head and Neck. Williams \& Wilkins, Baltimore, 1950.2 2) Bill, A.H. Jr. and Vandheim, J.L.: Cysts, Sinuses and Fistulas of the Neck Arising from the First and Second Branchial Cleft., Ann. Surg. 142: 904, 1955.
3) Wengelowski, R.: Ueber die Halsfisteln und Cysten., Arch. Chir., 98: 151, 1912. 4) Frazer, E.T.: "A Manual of Embryology" 2 nd Ed. Bailere, Tindall and Cox, London, 1940. 5) Richards, L.: Congenital Atresia of External Auditory Meatus. Ann. Otol., Rhin. \& Laryng, 42: 692, 1933. 6) Garrett, F. D.: Development of the Cervical Vesicles in Man., Anat. Record, 100: 101 $\sim 113,1948.7$ 7) Heuzinger: Hals-Kiemen-Fisteln non noch Nicht Beobachteter Form. Virchow's Arch. f. Path. Anat., 29: 358 380, 1864. Bland Sutton, J.: On Branchial Fistulae, Cysts, Diverticula, and Supernumerary Auricles. Jour. Anat. and Physiol., 21 : 289 298, 1887.9 9) Rabl, C.: Zur Bildungsgeschichite des Hals. Prag. Med. Woch., 11: 497, 12:3, 1886 1887. 10) Meyer, H.W.: Congenital Cysts and Fitulae of the Neck. Ann. of Surg. 95: 1 49, 1932. 11) Congdon, E.D.: Transformation of the Aortic-Arch System During the Development of the Human Embryo. Contributions to Embryology. 14, No. 68: 47 110, 1922. 12) Proctor, B.: Lateral Vestigial Cysts and Fistula of the Neck. The Laryngoscope, 65: 355 401, 1955. 13) Miller, J.B.: Branchial Cleft Cysts, Fistulae and Appendages. The Laryngoscope, 67: 1123 1193, 1957. 14) Lyall, D., and Stahl, W.M.: Lateral Cervical Cysts, Sinuses, and Fistulas of Congenital Origin. Internat'l Abst. Surg. SG \& O, 104: 417 434, 1956 . 15) Hollingshead: "Anatomy for Surgeons, Head and Neck. Paul \& Hoeber 1954. 16) 竹田䃡智夫: 先天性側頸壆，耳垁，27：128，1956 (昭 31)。

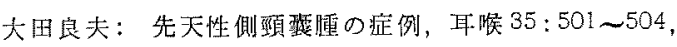
1963 (昭 38). 18) Pemberton, J. and Neel, H.B.: Lateral Cervical Cysts and Fistulas. Surg,, 18: 267, 1945. 19) Ladd, W.E. and Gross, R.E.: Congenital Branchial Anomalies. Amer. Jour. Surg., 39:234, 1938. $\quad$ 20) Bailey, H.: The Clinical Aspects of Branchial Cleft Cysts. Brit. Jour. Surg., 10: 565, 1922 1923. 21) Bhasker, S.N. and Bernier, J.R.: Histogenesis of Branchial Cysts. Amer. J. Path. 35; 467, $1959 . \quad$ 22) Hyndman, O.R. and Light, G.: The Branchial Appara- 
tus. Arch. Surg., 19:410, $1929 . \quad$ 23) Shaw, A., Santolli and Rankow: Cysts, Sinus and Fistulas of the First Branchial Cleft and Pauch. SG \& O 15:671，1962. 24) 関六郎：中耳儿交通せる先天性

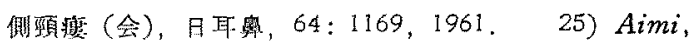
$K$. and Takino, K.: Anomaly of the First Branchial Cleft Arch. Otolaryng. 75: 397, 1962.

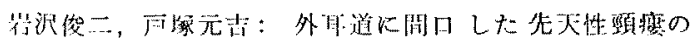
一例（会），日耳異，66:1218，1963. 27) Work, W.P., and Proctor, C.A.: The Otologist and First Branchial Cleft. Anomalies. Ann. Otol. Rhinol. \& Laryng. $72: 548,1963 . \quad 28)$ Druss, J.G. and Allen, B.: Congenital Fistula of the Neck Communicating with the Middle Ear., Arch. Otolaryng. 31 : 43, 1940. 29) Hoffman, E.: Branchial Cysts Within the Parotid Gland., Ann. Surg. 152: 290, 1960. 30) Sobieski, E.J. et al.: Branchiogenic Cyst Within the Parotid Gland, Arch. Otolaryng. 82: 395, 1965. 31) Hevener, E.P., and Clark, C.E.: Adenolympnoma., Surg. Gynec. Obstet. 90: 746 751, 1950. 32) Himmalstein, M.R.: New Concepts in Correlation of Surgical Anatomy and Embryology in Lateral Cervical Vestigeal Structures., The Laryngoscope, 98: 1727 1769, 1958. 33) Baumgartner, C.J.: Lateral Cysts and Fistulas of the Neck., Calif. Med., 76: 466 472,

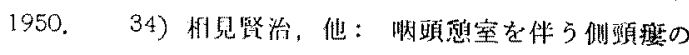
一症例（会），日耳邪，65:1205，1962（昭 37)。 35) 高椎裕, 他：先天性側預瘦の舆味ある一例 (会), 日, 外学会誌, 62:297.1961 (炤 36). 36) 伏田宏: 側頙瘦の一例 (会)，日耳摩，64:1469，1961 (昭 36).

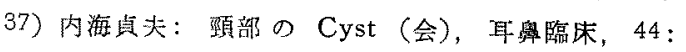

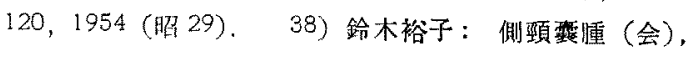
奈良医学雠誌，1：132，1956（昭 31）。 39）広戸幾 | 郎: 先天性完全侧傾庭の一異型 Grenzdivertikel $\emptyset$

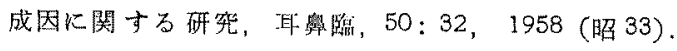
40) Raven, R.W.: Pauches of the Pharynx and Esophagus with Special Reference to the Embryological and Morphological Aspects., Brit. J. of

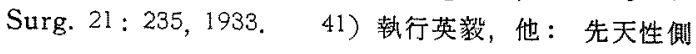

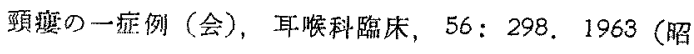
38). 42) Hicks, S.P.: Embryology and Pathology of Branchial Cleft Cysts. Surg. Clin., N.A.,
619,1953

43) Lyall, D.:

Congenital Cyst of the Third Branchial Cleft. Arch. Otolaryng. 64: 540, 1956.44$)$ Von Volkman, R.: Das Tiefe Branchiogenen Haslcarcinom. Zentralbi. f. Chir, 25 : $1073,1882$. 45) Lorenz, H.E.: Das Branchiogene Carcinoma. Bruns. Beitr. z. Klin. Chir. Tubing., 85: 599, 1913. 46) Martin, H. et al:: The Case for Branchiogenic Cancer (Malignant

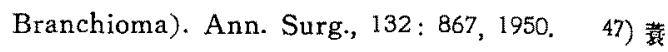

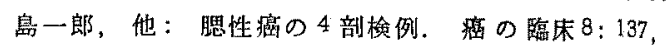
1962 (昭 37)。

\section{附図説明}

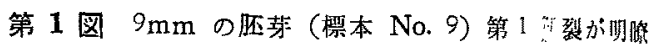
第 2,3,4 鰓裂は頸洞にらくまれる。

第 4 図 $8 \mathrm{~mm}$ の压芽 (標本 No. 8) $\times 25$

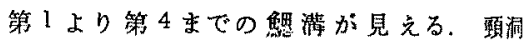
(CS) は広く閶いている。第 4 鰓潾の部位に

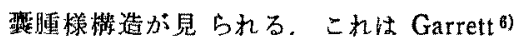
の記载する上皮板である。

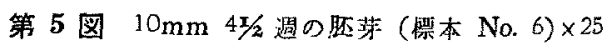

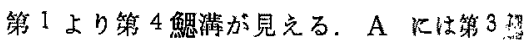
虂か. 胸腺咽顽管 (TD) が 発生し下行する

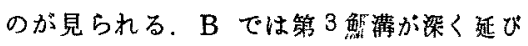
㸶嘼例䐴に接近している。

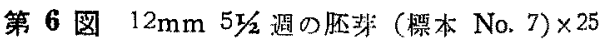
筙1 薢襄上り発生する欧氏管 (E) の形成が

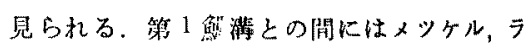

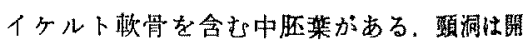

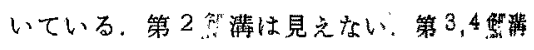
が痕跡的に見られる。

第 7 图 $17 \mathrm{~mm}$ 肧芽 (醥本 No. 3) ×15

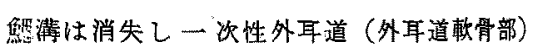
は浅い陷凹となつている（矢印）耳具形成は 末た見られない

第 8 图第 7 图の標本 (No. 3) の水平断面 $\times 50$ 外耳道と欧氏管原基の間にはメッケル，ライ ケルト軟骨を含を中肧集がある。

第 10 図 $50 \mathrm{~mm} 12$ 週の胎坚（標本 No. 1) $\times 10$ 耳介の形成が見られる。

第11图 第 10 図の標本 (No. 1) の前頭断 $\times 50$ 細い索状の外耳道上皮板が中耳の方向飞延び 中耳腔との間に鼓膜の形成が始まつている。 外耳道内腔は末完成である。 
相見論交 附図(I)

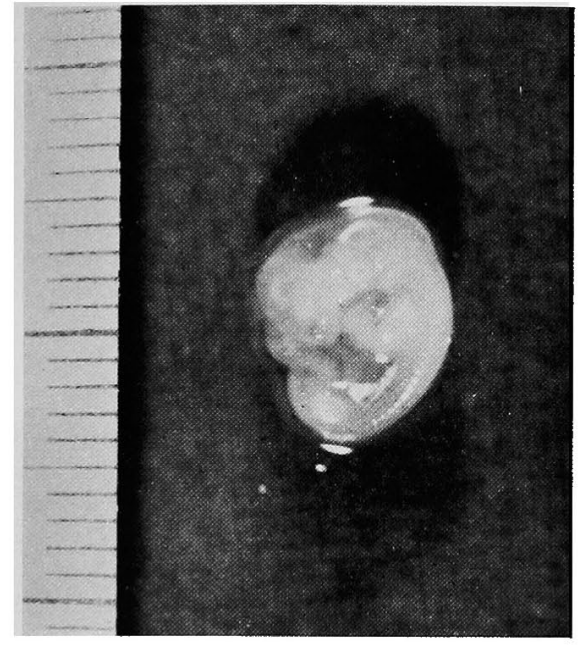

第 1 図

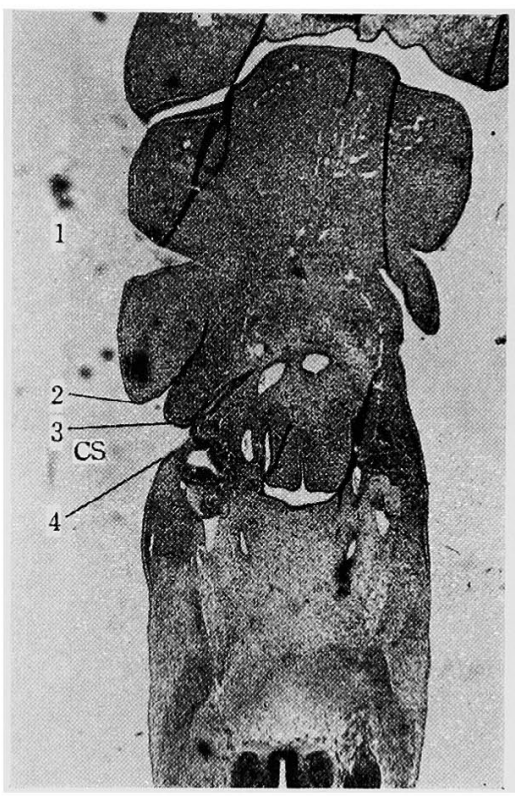

第 4 図

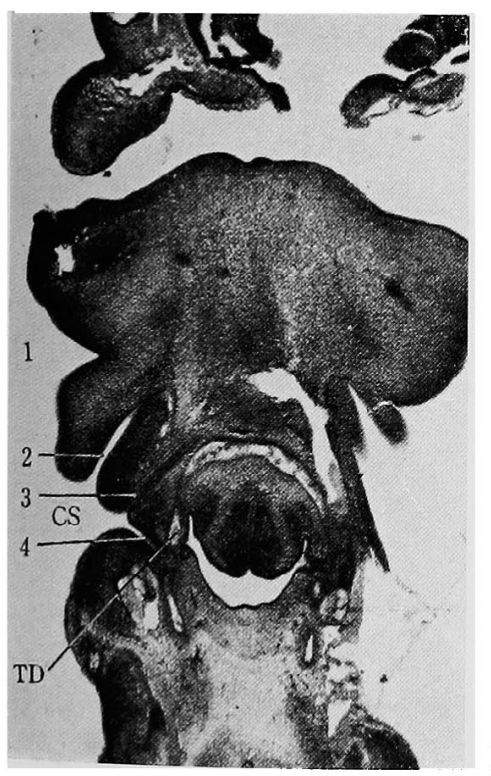

第 5 図 A

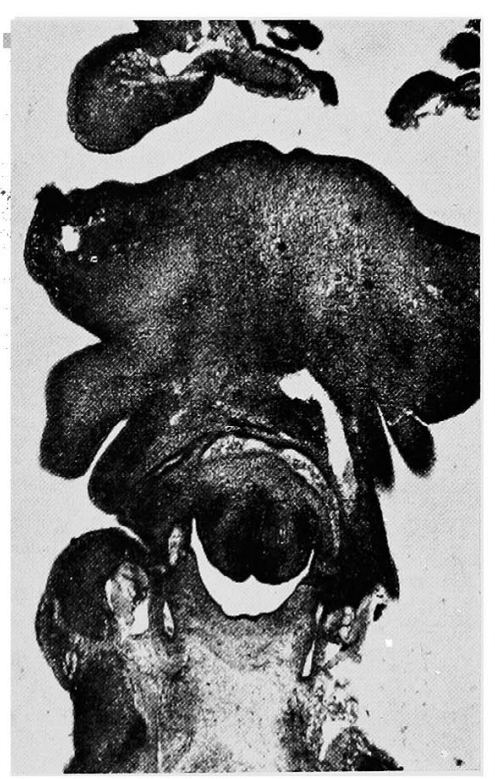

B

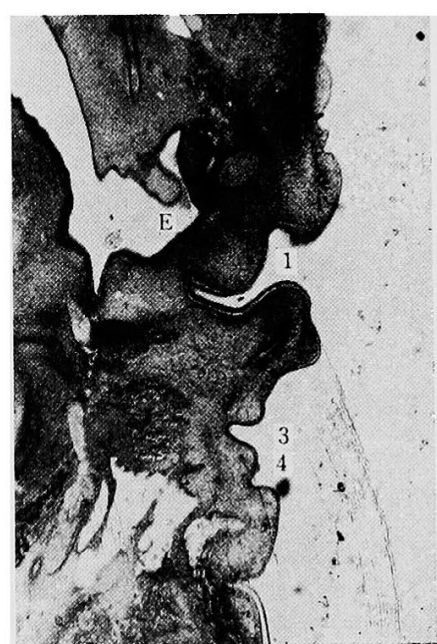

第 6 図 
相見論文 附図（II）

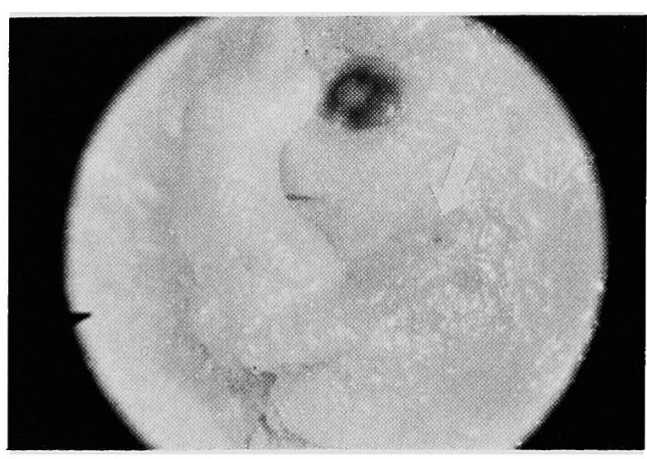

第 7 図

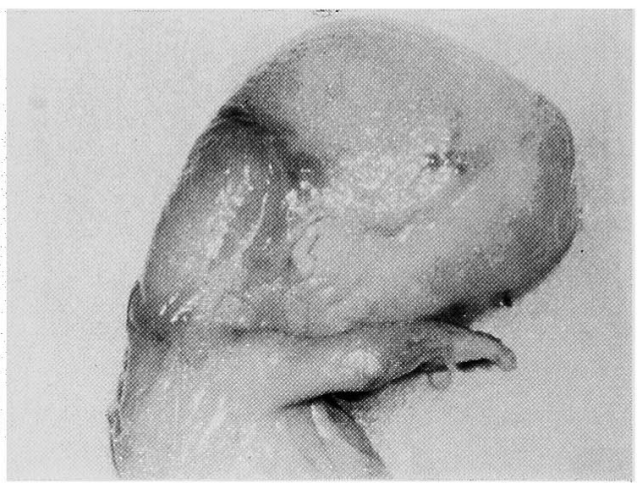

第 10 図

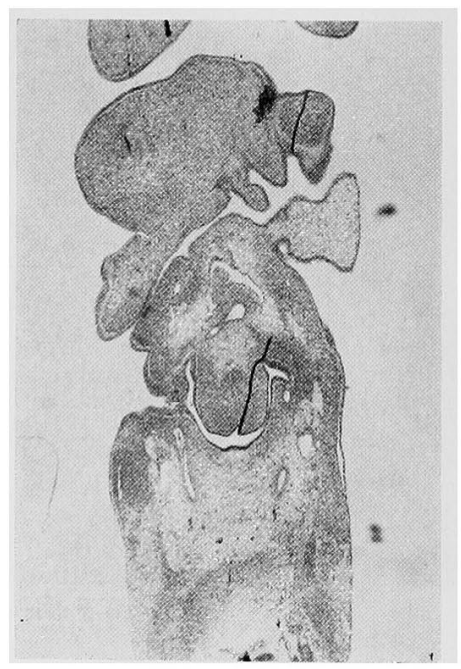

第 12 図

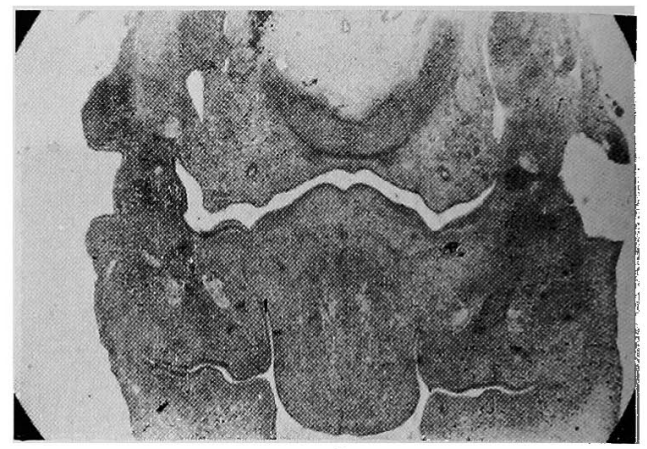

第 8 図

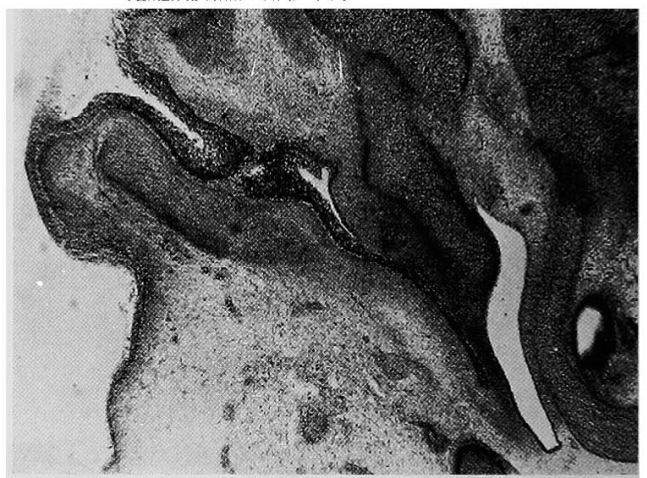

第 11 図

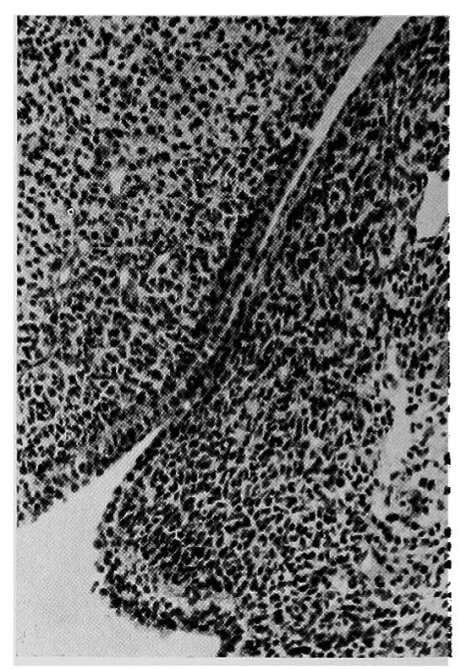

第 13 図 
相見論文 附図（四）

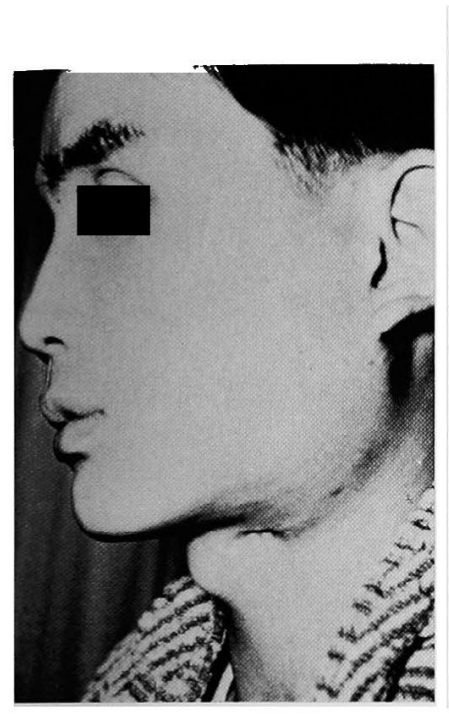

第 18 図
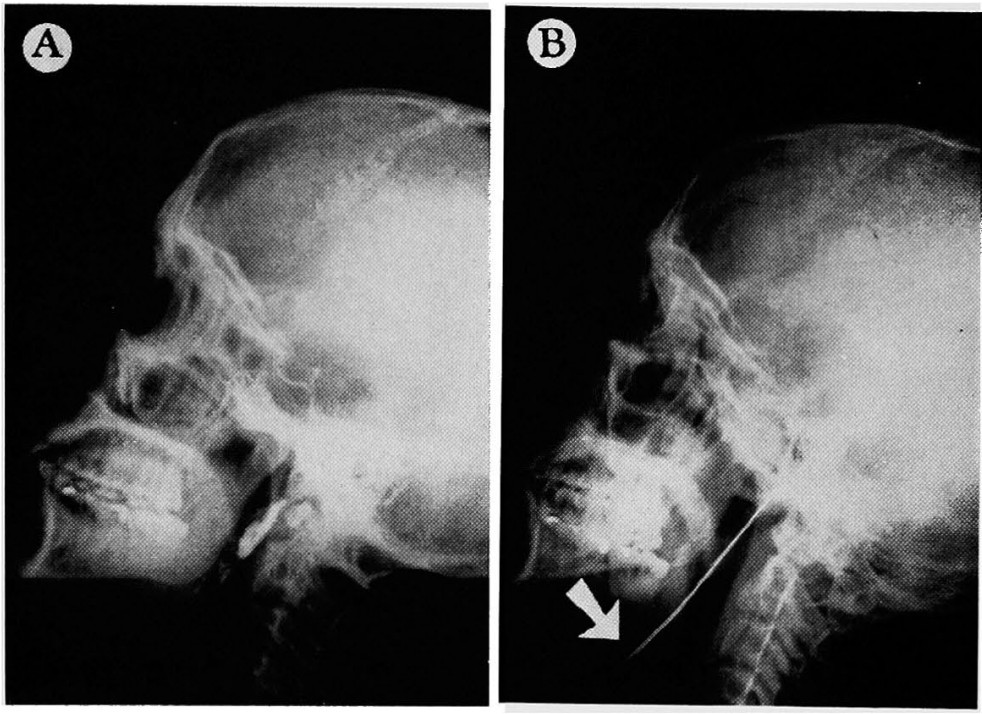

第 19 図

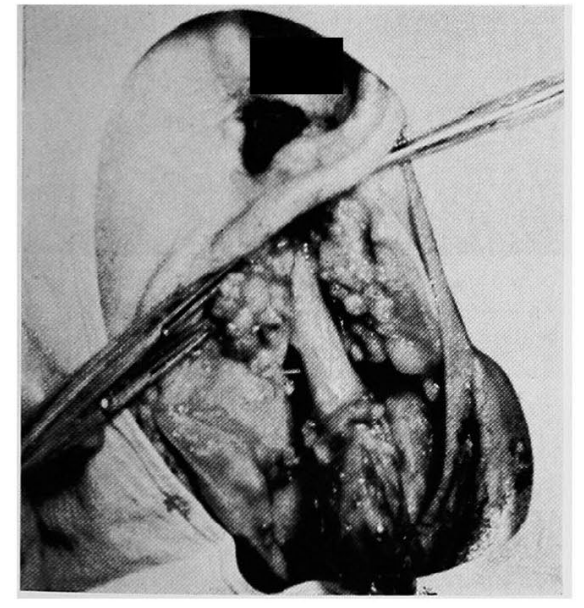

第 20 図

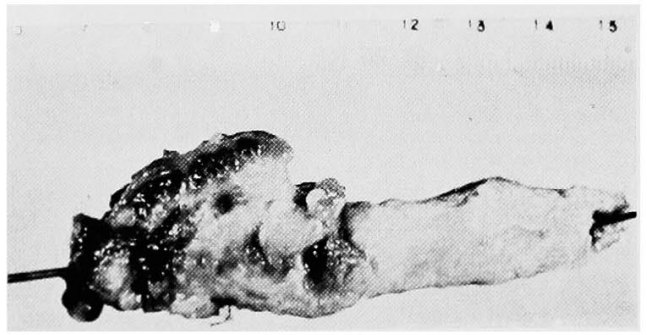

第 21 図 
相見論交附図 (N)

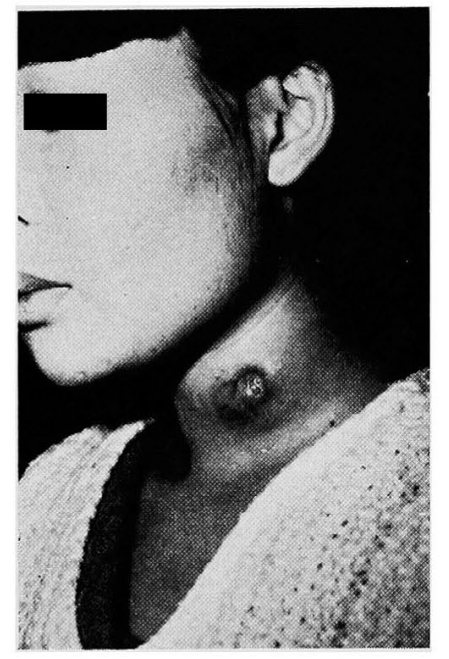

第 22 図

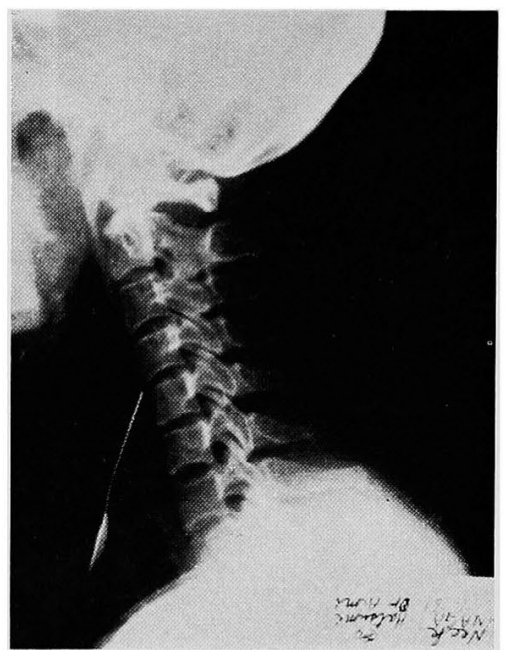

第 23 図

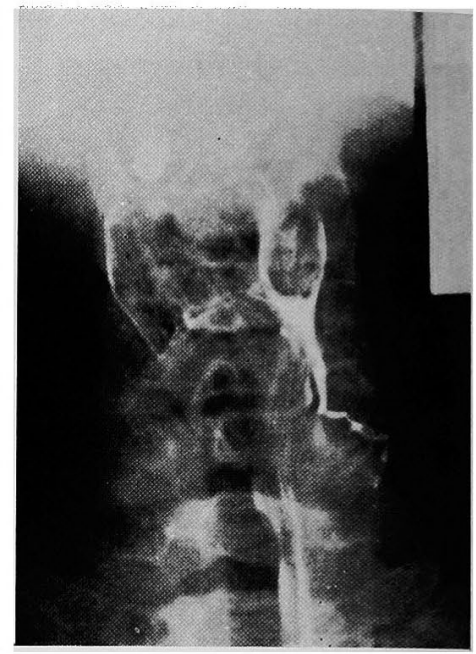

第 24 図

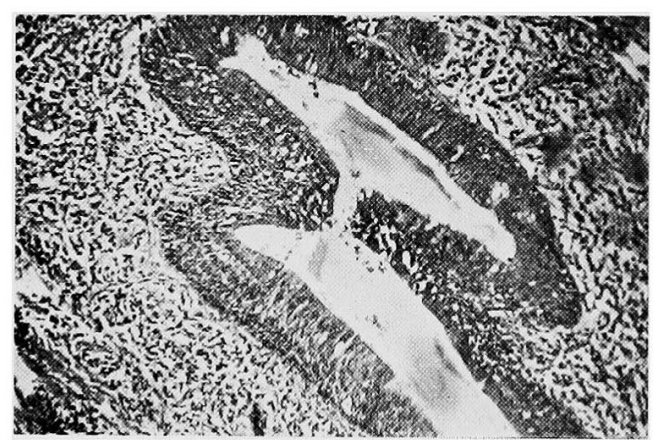

第 25 図

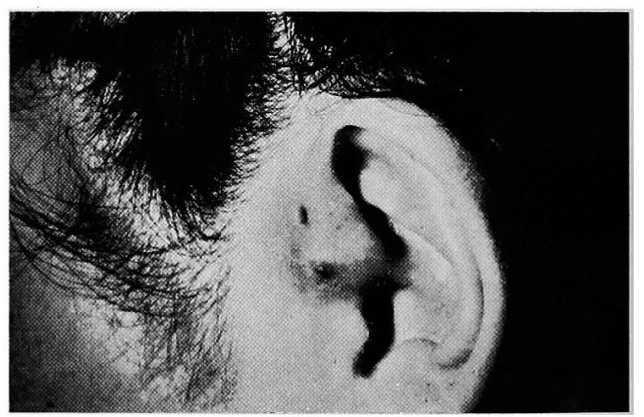

第 26 図

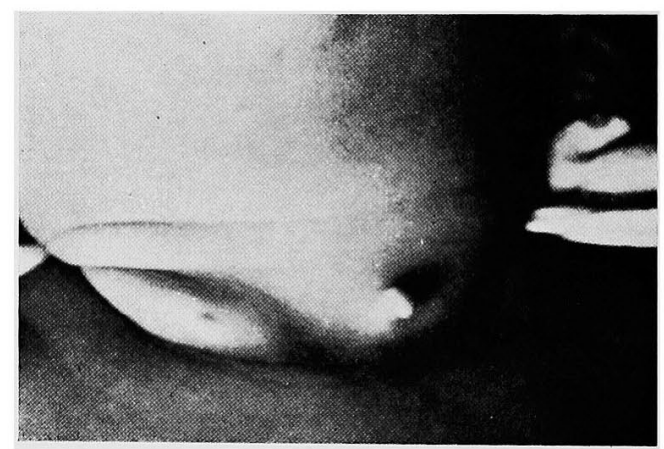

第 27 図 
第 12 図 $8 \mathrm{~mm}$ の肧芽（票本 No. 8) × 25 に見られる 第 2 䰻裂の閉鎖膜の形成又この標本では第 4 鰓淟が上皮板を経て咽頭側壁に接しているの が見られる。

第13図第 12 図に見られる第 2 鮊裂の閉鎖膜を払大 したもの $\times 100$ 外肧葉側は重層殿平上皮，内 坏藮側は単層立方上皮からなる。

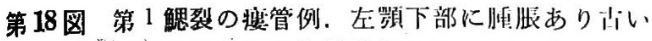
ら切開創ははんこん性份纱となっている。

第19图 A 溜管内にリピオドールを沫入した所 B 淁管队にン゙ンデを插入. 先端は外耳道に 接している。矢印は皮㾍開部

第20园焣下腺下部を切開し外耳道に通ずる太い埴管 を摘出した。

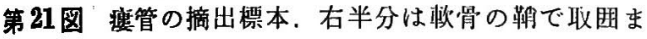
れている。

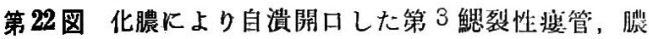

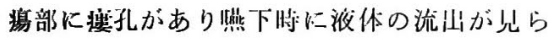
れる。

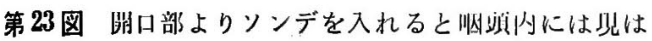
扎が，先端は梨子状得に一致する。
第 24 図 バリウムによる瘦管造影では紗錘状咽頭刑室

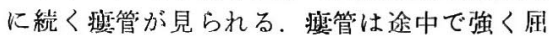
曲して皮處面に開口する。

第 25 図蝗管の細い部分の䉼面図 $\times 100$ 内腔は線毛 上皮で周困に豊富なリンパ細胞が見られる。

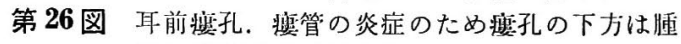
㸟し膿栓形成が見られる。

第 27 図生後 1 週間の男児に見られる湏部-耳:

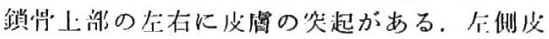
咸突起物の攴下には忺骨様組織を螌孔る。

和を終るに臨み御指導，御校阅を晹つた恩所、鈴 木安恒教授に梁謝致します 又本破究の当初から終

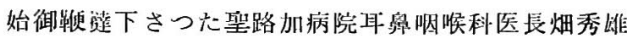
博土に深く御礼申し上げます

本論文の 1 部は詔和 36 年 2 月第 376 回耳與関宣

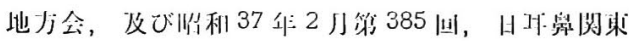
地族に打いて教告した。

（愿㭻到着 $=$ 临和41.6.3日）

\section{欧 米 製 新 型 補 聴 器}

\section{Bonochord 英国ボノコード \\ 英国の代表的メーカーとして世

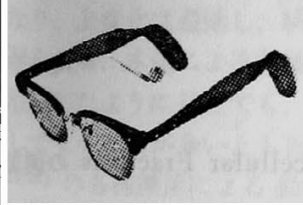 \\ Ardente

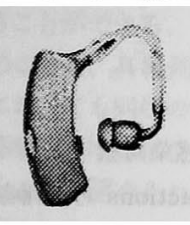 \\ に問うホノコード社B 05 型メ ガネ式補㯖器は最高の性能とス マートさを誇り軽くて耐久性に 富んでいるので、最も多くの人 々に使用きれでおります。 \\ 英国アーデント \\ 此の耳掛式は世界最小の器械 て高性能の人目につかない理 想的な補聴器です。重さ䄪 $5.5 \mathrm{~g}$ で4 石のトランジスターを有 し、特に御娵人の埸合は瑟の 中に入りますので、外部より 全く判りません。}

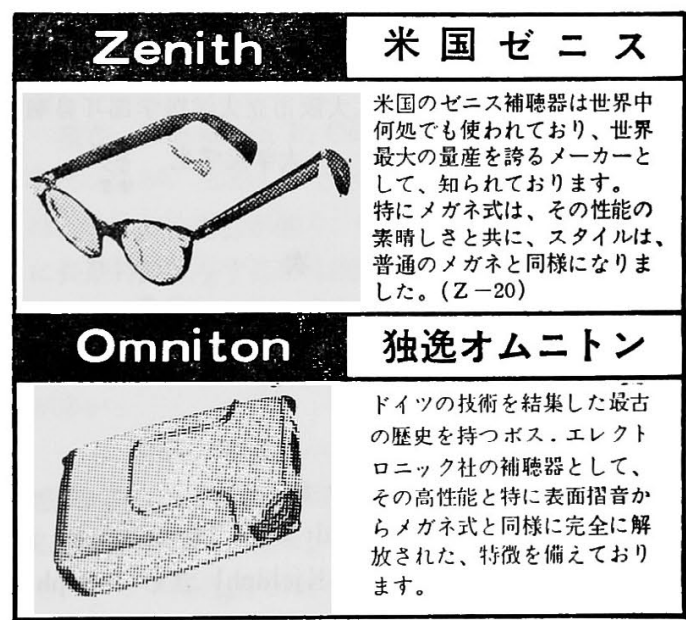

\section{英国ボノコード アーデント 米国ゼニス・独乙オムニトン 補聴器輸入発売元}

欧米国産各種補聴器販売 補 聴 器 専門 店
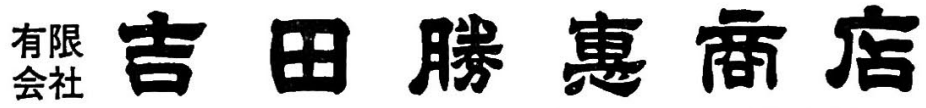

東京都中央区日本橋堀留町 $2 / 8$

TEL (661) 4370 (662) 2988

大阪支店 大阪市西区靶本町 $2 / 71$ T E L (441) 3023

岡山支店 岡 山市界大学町 1956 T E L (2 2) 92208 